\title{
Ancient Oil as a Source of Carbonaceous Matter in 1.88-Billion-Year-Old Gunflint Stromatolites and Microfossils
}

\author{
B. Rasmussen, ${ }^{1}$ J.R. Muhling, ${ }^{1}$ and W.W. Fischer ${ }^{2}$
}

\begin{abstract}
The 1.88-billion-year-old Gunflint carbonaceous microfossils are renowned for their exceptional morphological and chemical preservation, attributed to early and rapid entombment in amorphous silica. The carbonaceous matter lining and partly filling filamentous and spherical structures is interpreted to be indigenous, representing thermally altered relicts of cellular material (i.e., kerogen). Here we show that stromatolitic black cherts from the Gunflint Formation, Schreiber Beach, Ontario, Canada, were saturated in syn-sedimentary oil. The thermally altered oil (pyrobitumen), which occurs in the stromatolites and intercolumn sediments, fills pores and fractures, and coats detrital and diagenetic grain surfaces. The occurrence of detrital bitumen grains in the stromatolites points to the proximity of shallow seafloor oil seeps and hence the possible existence of chemosynthetic microbes degrading hydrocarbons. We suggest that hydrocarbons that migrated through the silicifying stromatolites infiltrated semi-hollow microbial molds that formed following silica nucleation on the walls or sheaths of decayed cells. Upon heating, the hydrocarbons were transformed to nanoporous pyrobitumen, retarding silica recrystallization and enhancing detailed preservation of the carbon-rich microfossils. Hydrocarbon infiltration of silicified microbes offers a new explanation for the preservation of the Gunflint microfossils and may have played a role in the formation of some of Earth's oldest microfossils. Key Words: Gunflint-Microfossils-Precambrian-Carbonaceous matter-Oil-Fossilization-Chert. Astrobiology 21, 655-672.
\end{abstract}

\section{Introduction}

M ICROFOSSILS HAVE BEEN reported in some of Earth's oldest rocks (Schopf and Packer, 1987; Walsh, 1992; Rasmussen, 2000; Furnes et al., 2004; Bengtson et al., 2017; Dodd et al., 2017), but their biogenicity is commonly questioned (Brasier et al., 2002, 2015; García-Ruiz et al., 2003; Wacey, 2009; Marshall et al., 2011; Grosch and McLoughlin, 2014). The identification of ancient biological structures is hampered by the multitude of geological processes that overprint and destroy primary morphological and chemical signals, as well as by abiotic processes that can produce structures and introduce compounds that mimic indigenous life (Brasier et al., 2002; Cady et al., 2003; García-Ruiz et al., 2003; Oehler and Cady, 2014). Some of the best-preserved Precambrian microfossils are from the $1.88 \mathrm{Ga}$ Gunflint Formation at Schreiber Beach along the northern shore of Lake Superior, Ontario, Canada (Tyler and Barghoorn, 1954; Barghoorn and
Tyler, 1965; Cloud, 1965; Awramik and Barghoorn, 1977; Knoll et al., 1978; Strother and Tobin, 1987; Lanier, 1989; Moreau and Sharp, 2004; De Gregorio et al., 2009; Planavsky et al., 2009; Wacey et al., 2012; Köhler et al., 2013; Shapiro and Konhauser, 2015; Alleon et al., 2016; Lepot et al., 2017). The discovery was made by Stanley Tyler, who was tracing the easternmost extent of iron formations of the Gunflint Formation. Unlike most iron formations, which are stained red by the presence of iron oxides, the outcrop comprised black stromatolitic cherts (Tyler and Barghoorn, 1954; Barghoorn and Tyler, 1965). Subsequent petrography revealed a variety of densely intertwined filamentous and spherical microfossils composed of a brown substance inferred to be organic matter. The remarkable preservation of ancient microfossils was attributed to early silica cementation and hinted at the existence of a vast fossil record in black chert stretching back into the early Archean. The sheer abundance and detailed preservation of the carbonaceous microfossils has made the Gunflint a

\footnotetext{
${ }^{1}$ School of Earth Sciences, The University of Western Australia, Perth, Australia.

${ }^{2}$ Division of Geological and Planetary Sciences, California Institute of Technology, Pasadena, California, USA.
} 
yardstick with which all new discoveries have been compared. However, despite subsequent discoveries, only a tiny fraction of Precambrian cherts are known to preserve bona fide microfossils.

Experiments and studies of modern siliceous hot springs suggest that microbial cell walls, sheaths, and cytoplasm act as nucleation sites for silica precipitation, preserving morphological information (Schultze-Lam et al., 1995; Cady and Farmer, 1996; Westall, 1999; Jones et al., 2001; Konhauser et al., 2001; Lynne and Campbell, 2003; Orange et al., 2009, 2012; Gong et al. 2020). The accompanying degradation of cellular organic matter leads to the formation of semi-hollow molds encased in initially porous silica cement. The rapid decomposition of organic molecules in experiments and modern silicifying environments (e.g., Gong et al., 2020) raises questions about the origin of carbonaceous matter in Precambrian microfossils. Indeed, an external source of carbon has been suggested for some carbonaceous microfossils, either abiotic hydrocarbons derived from Fischer-Tropsch-type synthesis (Brasier et al., 2002; Lindsay et al., 2005) or oil generated via hydrothermal maturation of organic-rich shales (Rasmussen and Muhling, 2019a).

This study investigates the origin of carbonaceous matter in microfossils from stromatolitic black chert of the Gunflint Formation at Schreiber Beach. The Gunflint Formation comprises granular iron formation and stromatolitic chert
(Goodwin, 1956; Floran and Papike, 1975) and was deposited in a back-arc extensional basin that was transformed into a foreland basin at $\sim 1860 \mathrm{Ma}$ during the Penokean orogeny (Hemming et al., 1995; Fralick et al., 2002). A felsic tuff in the upper part of the formation yielded a U-Pb zircon age of $1878.3 \pm 1.3 \mathrm{Ma}$ (Fralick et al., 2002), and a distal ejecta layer linked to the Sudbury impact (1850 Ma) occurs immediately above the formation (Addison et al., 2005). The deposition of the iron formation has been linked to the upwelling of $\mathrm{Fe}^{2+}$-bearing deeper water onto a shallow shelf (Cloud, 1973; Poulton et al., 2004). The Gunflint iron formation is broadly correlative with other iron formations around the Lake Superior region and iron formations elsewhere in the world, which were deposited between 1.90 and $1.85 \mathrm{Ga}$ during an interval of global mafic magmatism (Rasmussen et al., 2012).

\section{Samples and Methods}

Stromatolitic black chert of the 1.88-billion-year-old Gunflint Formation is exposed as isolated outcrops along the northern shore of Lake Superior west of Schreiber, Ontario, Canada (Barghoorn and Tyler, 1965; Cloud, 1965). At Schreiber Beach, the Gunflint Formation comprises thin layers of predominantly black, stromatolitic chert that overlie a basal mafic conglomerate (Fig. 1A, 1B). The siliceous
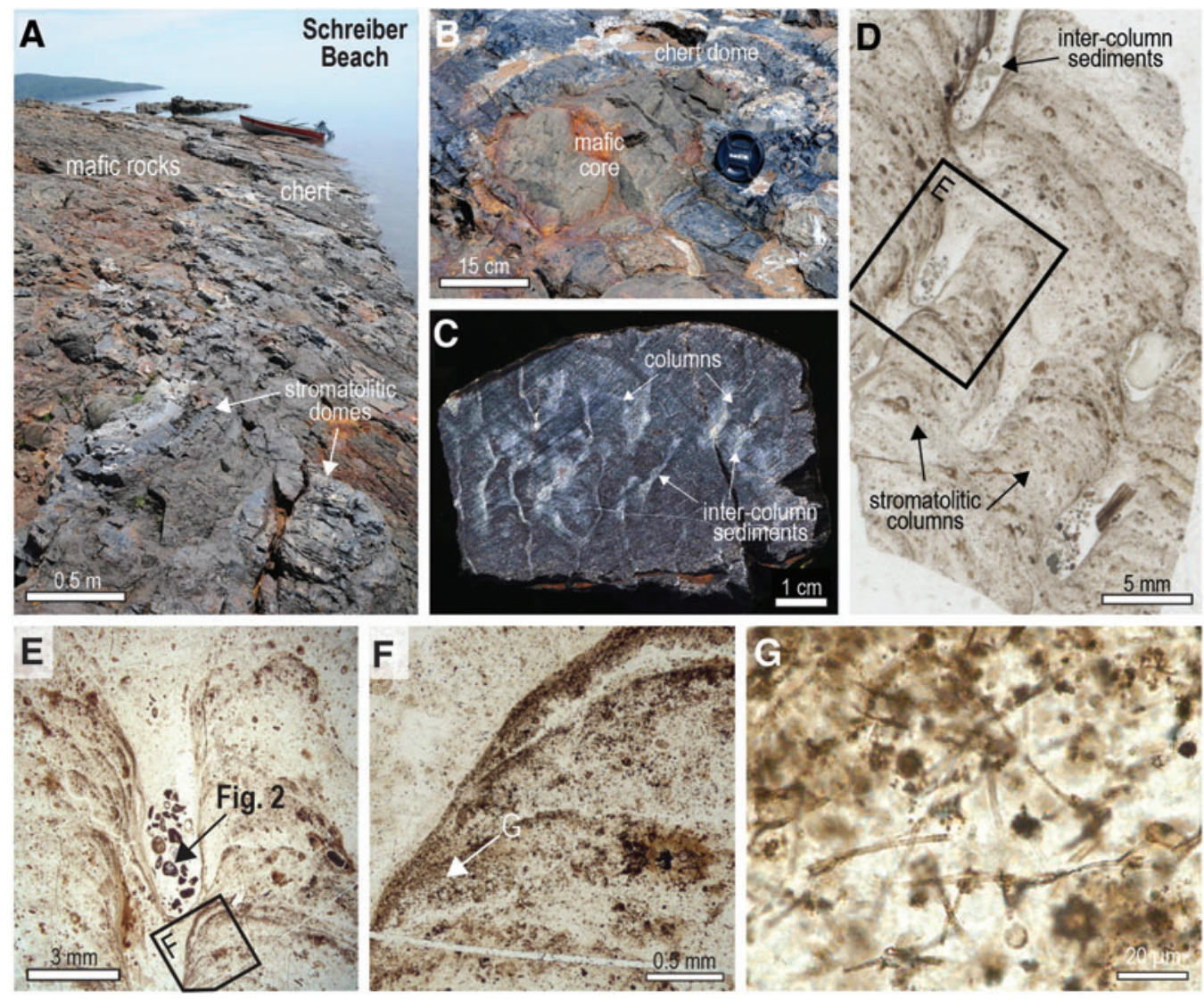

FIG. 1. Gunflint Formation from Schreiber Beach, Ontario. (A, B) Outcrop of stromatolitic black chert overlying mafic conglomerate. (C) Hand specimen of centimeter-sized branching stromatolitic columns separated by intercolumn sediments (see arrows). (D, E) Plane polarized light (PPL) image of stromatolitic column and intercolumn sediments. (F, G) PPL images of stromatolite layers with filamentous (Gunflintia minuta spp.) and spherical (Huroniaspora spp.) microfossils delineated by carbonaceous matter (brown). Color images are available online. 
stromatolitic domes, which are up to $1.5 \mathrm{~m}$ in diameter and up to $45 \mathrm{~cm}$ high (Barghoorn and Tyler, 1965), contain convex-upward laminated columns up to $1 \mathrm{~cm}$ thick and up to $10 \mathrm{~cm}$ long (Fig. 1C, 1D).

In this study, we examined samples of black chert from scattered outcrops to the west and east of the Schreiber Channel Provincial Nature Reserve. The morphology and texture of these samples are identical to those from outcrops from the reserve. Polished thin sections were prepared from 20 samples of stromatolitic black chert and gray laminated chert from the Schreiber Beach area.

Each polished thin section was examined by optical and scanning electron microscope. Scanning electron microscopy (SEM) was used to locate the carbonaceous microfossils within chert prior to in situ extraction using focused ion beam (FIB) milling. Optical microscopy and scanning electron microscopy-energy dispersive X-ray spectrometry (EDS) was carried out to identify mineral phases and determine their composition. Lamellae for transmission electron microscopy (TEM) analyses were cut from polished thin sections of black chert containing abundant filamentous microfossils. The lamellae are typically $10 \mu \mathrm{m}$ by $5 \mu \mathrm{m}$ and $0.1 \mu \mathrm{m}$ thick. Bright-field TEM, high-angle annular dark-field (HAADF) and bright-field scanning transmission electron microscope (STEM) images were collected and processed by using TIA (TEM Imaging and Analysis) software from FEI. Qualitative EDS spectra and element maps were collected and processed with an FEI Super X EDS detector and processed with Bruker Esprit software.

\section{Results}

\subsection{Stromatolitic black chert}

Petrographic examination of black chert from samples of large stromatolitic domes reveals abundant, closely packed columns ranging in width from a few millimeters up to a centimeter. The columns are internally laminated, comprising convex upward laminae that steepen to near vertical along the side of the columns (Fig. 1D-1F). The columns comprise almost entirely chert and chalcedony, whereas the laminae are defined by trace amounts of carbonaceous matter and pyrite.

The intercolumn zones, which are $0.1-1 \mathrm{~cm}$ apart, contain mainly ooids, granules, and intraclasts composed of chert (Fig. 2) with trace amounts of carbonaceous matter, greenalite, siderite, pyrite, and other phases. Rare grains of detrital quartz, zircon, chromite, and apatite are also present. The detrital grains are enclosed in cement comprising mainly chert and chalcedony, with minor pyrite, ankerite, and carbonaceous matter. Locally, laminae between stromatolitic columns drape across the intercolumn sediments.

The black color of the chert in outcrop and hand specimen from Schreiber Beach is due to the presence of finely dispersed carbonaceous matter and, in some cases, minute sulfide crystals (mainly pyrite). In thin section, solid masses of carbonaceous matter are black in transmitted light and brown in reflected light. In regions where the carbonaceous matter is more finely dispersed, the chert ranges in color from dark brown to pale amber in transmitted light.

FIG. 2. Chert ooids and intraclasts between stromatolitic columns, Schreiber Beach. (A-C) Plane polarized light (PPL) images (A, B) and reflected light (RL) image (C) of ooid with dark lamellae containing carbonaceous matter (CM). (D-F) PPL (D, E) and RL (F) images of chert ooid with carbonaceous matter (black) filling interstitial cavities between euhedral quartz crystals. (G) PPL image of detrital quartz grains between stromatolitic columns. (H) Cross-polarized light image of detrital quartz grain (qtz) "floating" in pore-filling silica cement. Color images are available online.
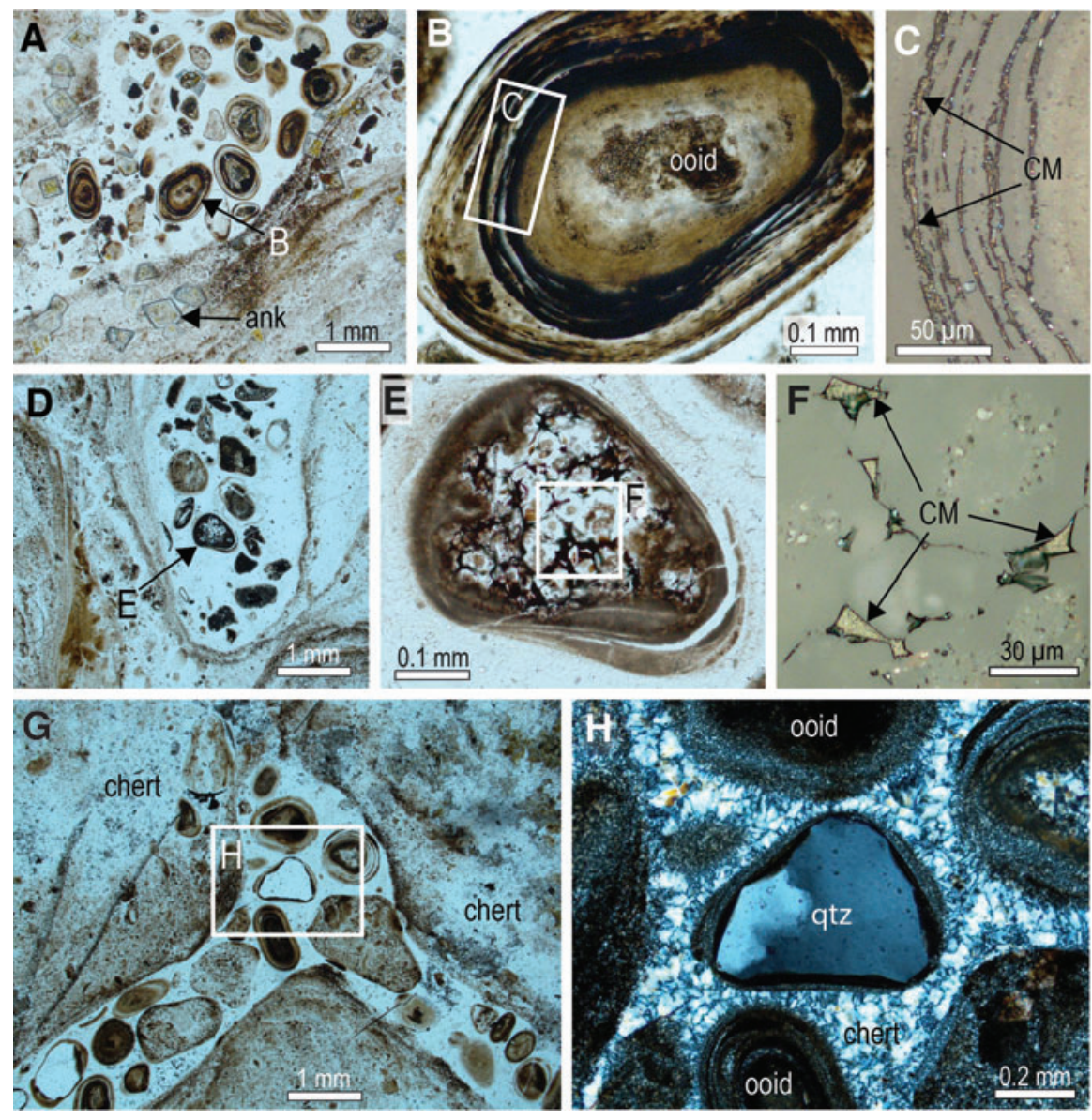
In reflected light, finely dispersed carbonaceous matter occurs on the surface of the slide as negative relief features (e.g., pits, grooves, holes).

\subsection{Microfossil morphology}

The fingerlike structures contain a rich assemblage of filamentous and spherical microfossils (Fig. 1G), as documented in earlier studies (e.g., Tyler and Barghoorn, 1954; Barghoorn and Tyler, 1965; Cloud, 1965; Awramik and Barghoorn, 1977; Knoll et al., 1978; Strother and Tobin, 1987; Lanier, 1989; Moreau and Sharp, 2004; Planavsky et al., 2009; Wacey et al., 2012; Shapiro and Konhauser, 2015; Alleon et al., 2016; Lepot et al., 2017). The intertwined filaments and coccoidal structures appear to "float" in a matrix of chert (Fig. 1G), suggesting that the microorganisms were encased in amorphous silica before compaction, during very early diagenesis. The biological affinity of these microfossils is uncertain, although Wacey et al. (2013) argued that the main Gunflintia-Huroniaspora assemblage was a saprophytic, heterotrophic community, which included sulfate-reducing microbes. Using Fourier transform infrared microspectroscopy, Igisu et al. (2009) suggested that the chemistry of the carbonaceous matter is consistent with a bacterial rather than archaeal origin, whereas Lepot et al. (2017) argued that the relatively large cell size and presence of intra-microfossil Fe minerals are consistent with oxygenic photosynthesizers.
The most abundant microfossils are filaments of Gunflintia spp. and coccoids of Huroniaspora spp., which together comprise $>99 \%$ of the assemblage. The Gunflintia filaments have been divided into Gunflintia minuta, which vary from $0.8-2.5 \mu \mathrm{m}$ in width, and Gunflintia grandis, which are typically $>3 \mu \mathrm{m}$ in width. Gunflintia filaments were further divided into segmented and non-segmented types (Lepot et al., 2017). Huroniaspora have been split into at least two groups based on their diameter $(2-3 \mu \mathrm{m}$ and 7-9 $\mu \mathrm{m})$ and recently were further divided into thin-walled and thick-walled coccoids (Lepot et al., 2017).

\subsection{Carbonaceous matter in microfossils}

Examination by TEM shows that many of the larger Gunflintia filaments are lined by irregular films of carbonaceous matter between 50 and $300 \mathrm{~nm}$ thick. However, most of the filaments examined here lack clearly defined carbonaceous rims. Instead, the carbonaceous matter occurs in the interior of the filamentous microfossils, commonly between euhedral quartz crystals that typically coarsen inward (from $\sim 0.1$ to $2 \mu \mathrm{m}$ ) (Figs. 3 and 4 ). The apparent segmentation in many of the filaments when observed in transmitted light imaging can be seen by using SEM/TEM techniques to coincide with the presence of euhedral quartz crystals that are surrounded by interstitial carbonaceous matter (Fig. 3). The shape of the carbonaceous matter in the microfossils appears to be governed by the surrounding
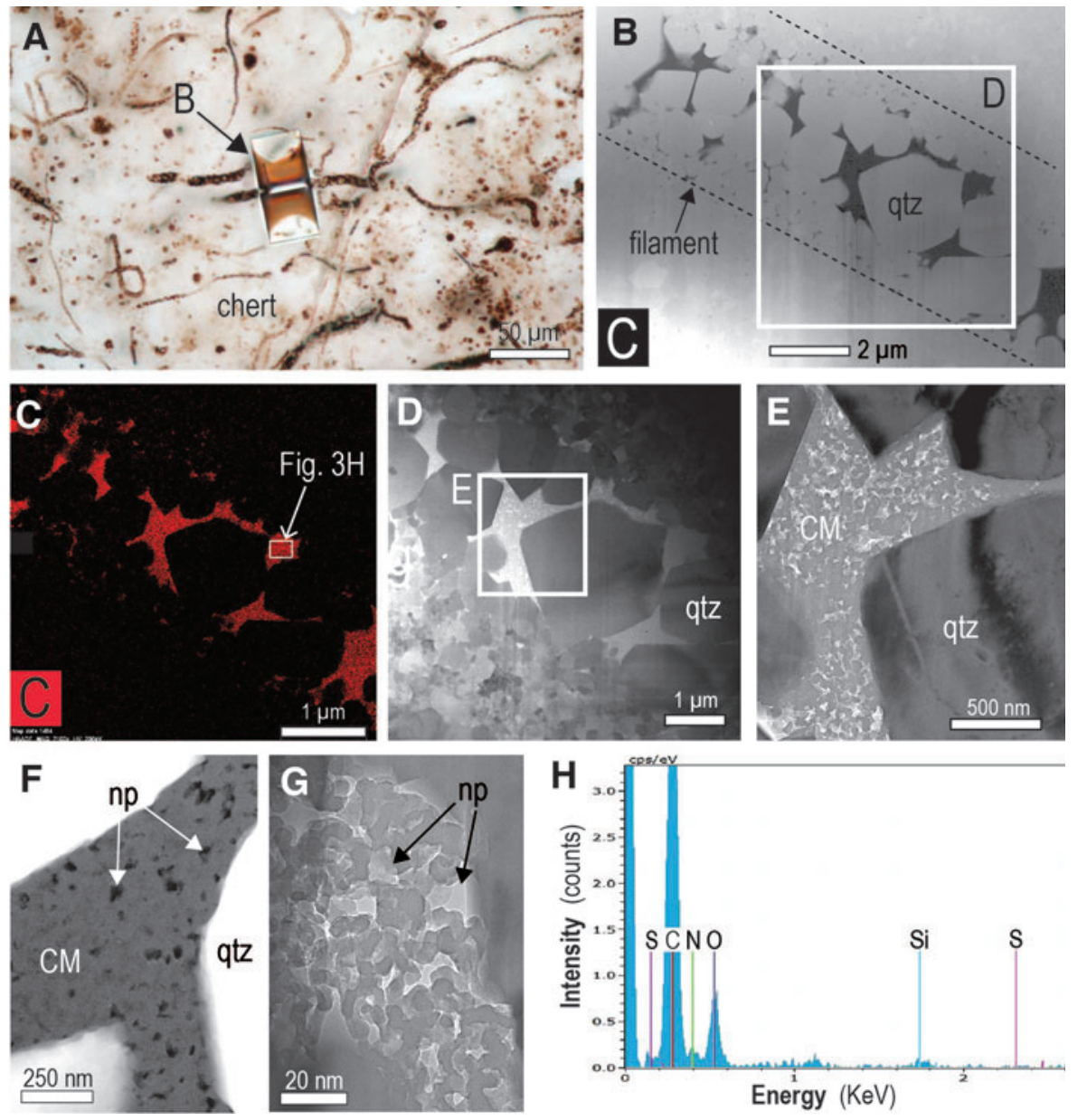

FIG. 3. Carbonaceous matter in Gunflint microfossils, Schreiber Beach. (A) Plane polarized light (PPL) image of dark, segmented filament with TEM foil excavation site along its length. (B) STEM dark-field image of foil cut along filament in (A). (C) TEM-EDS map of carbon (red) distribution along filament in (B). (D, E) STEM bright-field images of foil along filament showing carbonaceous matter (CM) occupying interstitial positions between euhedral quartz (qtz) in intracellular regions. (F) STEM dark-field image of carbonaceous matter (CM) in filament containing abundant nanometersized pores (black). (G) STEM bright-field image of nanopores (white) in carbonaceous matter in filament. (H) TEM-EDS spectra acquired from carbonaceous matter filling microfossil. Minor unlabeled peaks at $0.9 \mathrm{keV}(\mathrm{Cu})$ and $1.1 \mathrm{keV}$ (Ga) are artifacts from the TEM grid and $\mathrm{Ga}$ ion beam, respectively. Color images are available online. 
FIG. 4. Composition and texture of Gunflint microfossils, Schreiber Beach. (A) Plane polarized light (PPL) image of chert with abundant carbonaceous filaments, including one with TEM foil excavation pit. (B) STEM darkfield image of interstitial carbonaceous matter in filamentous microfossil in TEM foil extracted from (A). (C) TEM-EDS spectra acquired from carbonaceous matter in microfossil (see 4B). (D-G) TEM-EDS element maps for filament in (B), including carbon (D), silicon $(\mathrm{E})$, iron $(\mathrm{F})$, and oxygen (G). (H, I). STEM bright-field images of interstitial carbonaceous matter (CM) between fine-grained quartz (qtz) in filament (see inset in $4 \mathrm{~B}$ ). The carbonaceous matter contains a network of nanopores (white; np) and contains several plates of greenalite (grl). (J) STEM dark-field image of carbonaceous matter (CM) containing abundant nanometer-sized pores (black; np) and plates of greenalite (grl). Color images are available online.
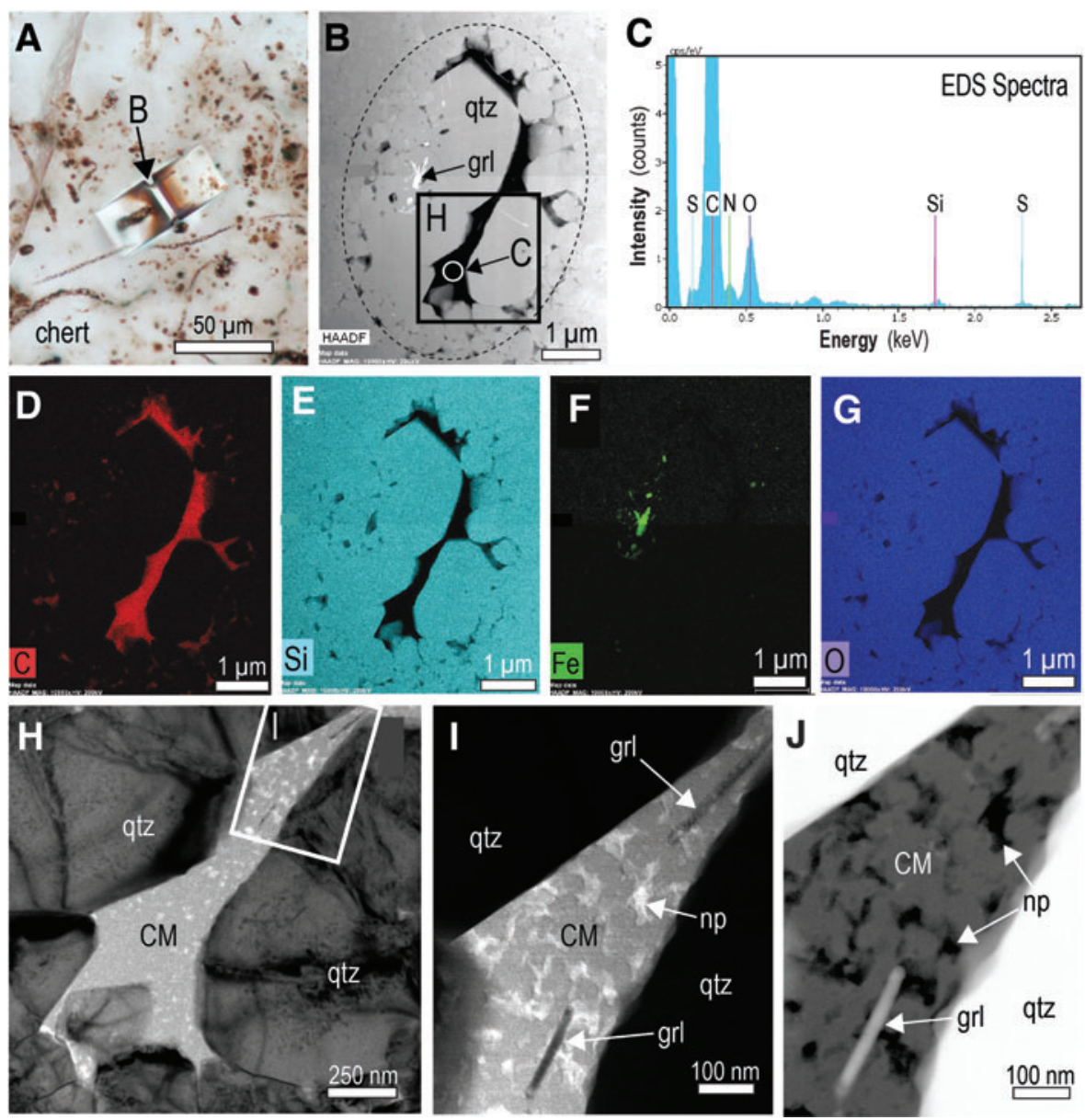

quartz crystals (Figs. 3 and 4). Most of the carbonaceous matter within microfossils contains a network of nanometersized pores typically $<50 \mathrm{~nm}$ wide (Figs. 3D-3G and $4 \mathrm{H}-$ $4 \mathrm{~J})$. An examination of previously published transmission electron microscope (TEM) images of carbonaceous matter from Schreiber Beach (e.g., Lepot et al., 2017) shows that nanoporous structures are common within Gunflintia minuta, Gunflintia grandis, and Huroniaspora microfossils (e.g., Fig. 1B, Supp. Figs. 4A, 6, 11B, 11C, and 12B in Lepot et al., 2017).

In some of the larger filaments, quartz crystals contain sub-micron-sized inclusions of greenalite and siderite (Fig. 4B, 4F), similar to observations made previously (Moreau and Sharp, 2004; Lepot et al., 2017). Nanoparticles of authigenic greenalite (up to $300 \mathrm{~nm}$ long and $25 \mathrm{~nm}$ thick) also occur in the carbonaceous matter between quartz euhedra filling filamentous microfossils (Fig. 4H-4J).

In some samples, small relicts of carbonaceous matter are enclosed in euhedral quartz crystals (Fig. 5). The carbonaceous matter ranges in shape from subspherical to irregular and is up to $300 \mathrm{~nm}$ in size ( $c f$. Moreau and Sharp, 2004). Many of the inclusions are associated with linear dislocations in the quartz crystals (Fig. 5I). The observed textural relationships are consistent with the presence of two phases of carbonaceous matter within the microfossils: an earlier phase engulfed by quartz crystals to form inclusions and a later phase occupying interstitial positions between inclusion-bearing quartz euhedra (Fig. 5).
Transmission electron microscopy-energy dispersive X-ray spectrometry spectra of the carbonaceous matter in Gunflint filaments and the stromatolitic chert show that it is composed of carbon with minor oxygen, nitrogen, and sulfur (Figs. 3H and 4C). Raman data from the Gunflint microfossils indicates that the structure of the carbonaceous matter is characteristic of poorly ordered carbon (Alleon et al., 2016). Recent Raman geothermometry of carbonaceous matter yields maximum temperatures of $150-170^{\circ} \mathrm{C}$ (Alleon et al., 2016) and $200-350^{\circ} \mathrm{C}$ (Papineau et al., 2017) from the Schreiber Beach locality.

\subsection{Carbonaceous matter in stromatolitic chert}

Solid masses of carbonaceous matter occur in fractures and veinlets in black chert from the Schreiber Beach locality (Figs. 6 and 7). Locally, chert adjacent to the fractures contains carbonaceous matter, which occupies interstices between microquartz crystals (Fig. 6D-6F), as observed in iron formation from the Gunflint Formation (Rasmussen and Muhling, 2019a). Carbonaceous matter also occurs as films and coatings around detrital chert and quartz grains (Fig. 8) and as solid grains (Fig. 6H, 6I). In some chert grains, the carbonaceous matter lines the outer oolitic layers (Fig. 2A-2C) and fills cavities between polygonal quartz crystals in the core (Figs. 2D-2F and 9A-9G). The interstitial position of the carbonaceous matter in the stromatolitic chert, occupying cavities between quartz crystals, 

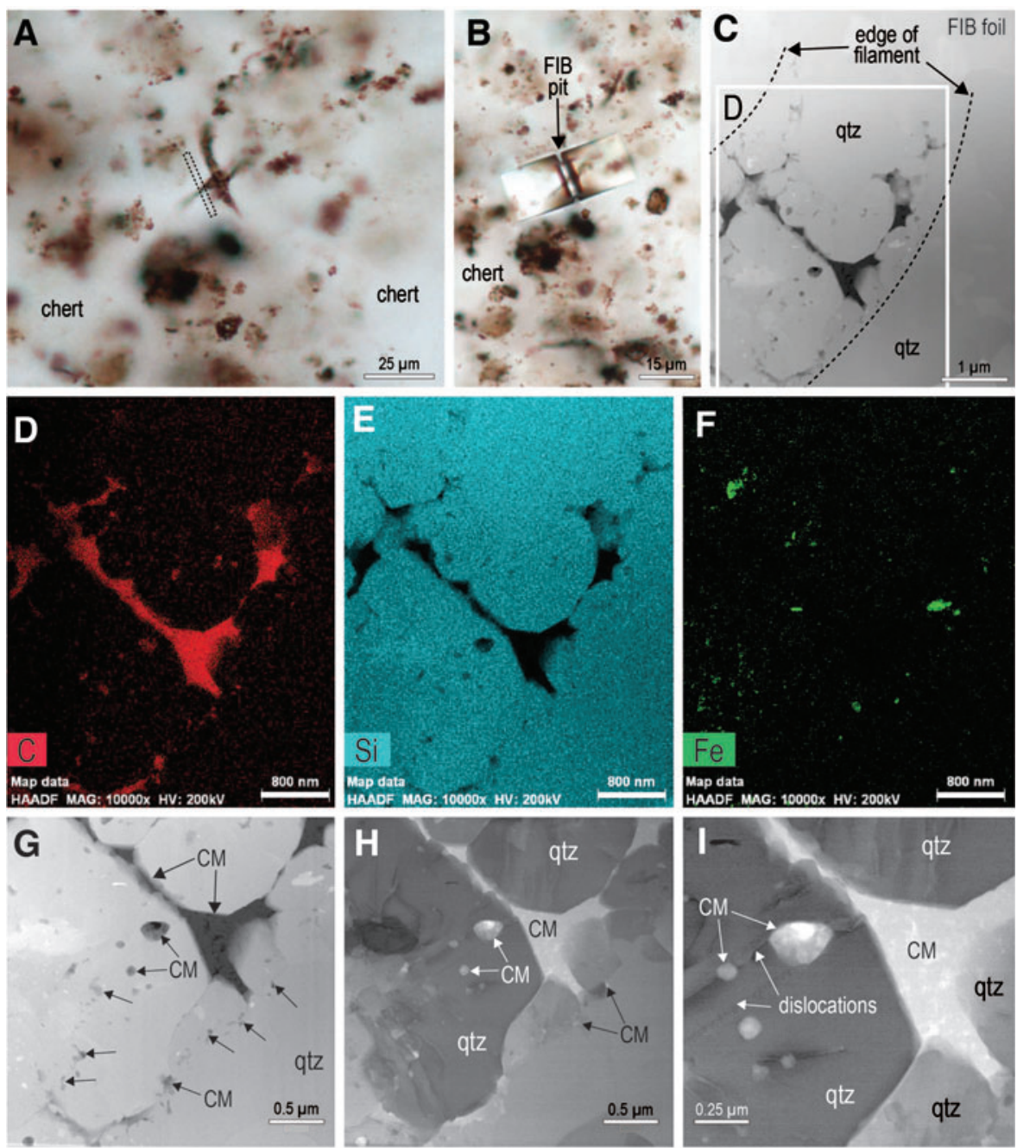

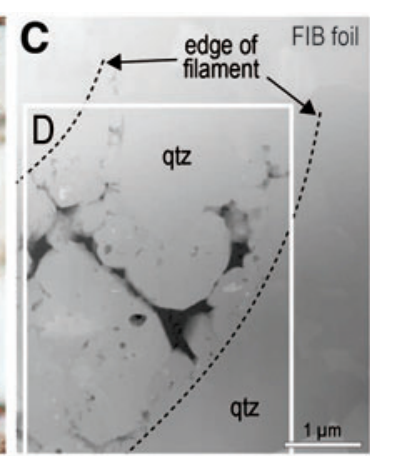

FIG. 5. (A, B) Plane polarized light (PPL) images of chert with abundant carbonaceous filaments, showing location of TEM foil excavation pit. (C) STEM dark-field image of interstitial carbonaceous matter in filamentous microfossil in TEM foil. (D-F) TEM-EDS element maps for filament in (C), including carbon (D), silicon (E), and iron (F). (G) STEM dark-field image of carbonaceous matter (CM) in inclusions within quartz crystals and occupying interstitial positions between quartz euhedra. (H, I). STEM bright-field images of minute inclusions of carbonaceous matter (CM) in quartz crystals (qtz) and occupying interstitial positions between fine-grained quartz (qtz). In (I), the inclusions of carbonaceous matter are associated with linear dislocations in the quartz. Color images are available online. resembles the distribution of carbonaceous matter within filamentous microfossils, albeit on a sub-micron scale (Figs. 3-5).

Very fine-grained relicts of carbonaceous matter locally produced brown diffuse bands discordant to layering within stromatolitic columns, as well as haloes around fractures, grains, and granules (Fig. 10). In places, isolated grains comprising mostly carbonaceous matter are preserved in stromatolitic chert (Fig. 11). In some samples, oval grains of solid organic matter with concentric shrinkage structures (Fig. 11C) coexist with detrital chert and quartz grains in a carbonaceous chert matrix (Fig. 11). Many of the fragments are angular and curvilinear (Fig. 11F, 11G) and appear to be fragments that exfoliated from organic-rich grains such as in Fig. 11C. Carbonaceous matter also occurs as semicontinuous masses that fill layers or the interior of millimeter-sized stromatolitic structures within larger laminated domes (Fig. 12).

In addition, bands of brown-stained chalcedony (Fig. 13A-13C), which occupies cavities in the stromatolitic columns and intercolumn chert, may contain relicts of interstitial carbonaceous matter. TEM-EDS analysis of FIB foils from the chalcedony confirms that the finely dispersed brown pigment is composed of carbonaceous matter, which is distributed along grain boundaries (Fig. 13D, 13E).
The brown chalcedony cement in the Gunflint stromatolites is identical to bitumen-stained chalcedony rims in the $\sim 340 \mathrm{Ma}$ Red Dog $\mathrm{Zn}-\mathrm{Pb}$ deposit (Rasmussen and Muhling, 2019b).

\section{Discussion}

\subsection{Distinguishing pyrobitumen from kerogen}

The amount of carbonaceous matter within microfossils is minor compared to that in the background chert matrix of the stromatolites and intercolumn sediments. Most of the carbonaceous matter is finely disseminated along irregular quartz grain boundaries or in microcavities lined by quartz euhedra. Differentiating indigenous organic matter (i.e., kerogen) from thermally altered migrated hydrocarbons (pyrobitumen) can be exceedingly difficult. However, because kerogen is a solid organic material, its shape commonly differs from that of oil that has been transformed into pyrobitumen.

The migration of oil through Phanerozoic sedimentary rocks can result in the development of organic films and coatings on mineral surfaces (Fig. 14A-14F). In some cases, fluid hydrocarbons can saturate the entire rock (Fig. 14G, $14 \mathrm{H})$ although oil infiltration is often not uniform, resulting in a patchy distribution (Fig. 14G), not dissimilar to the 


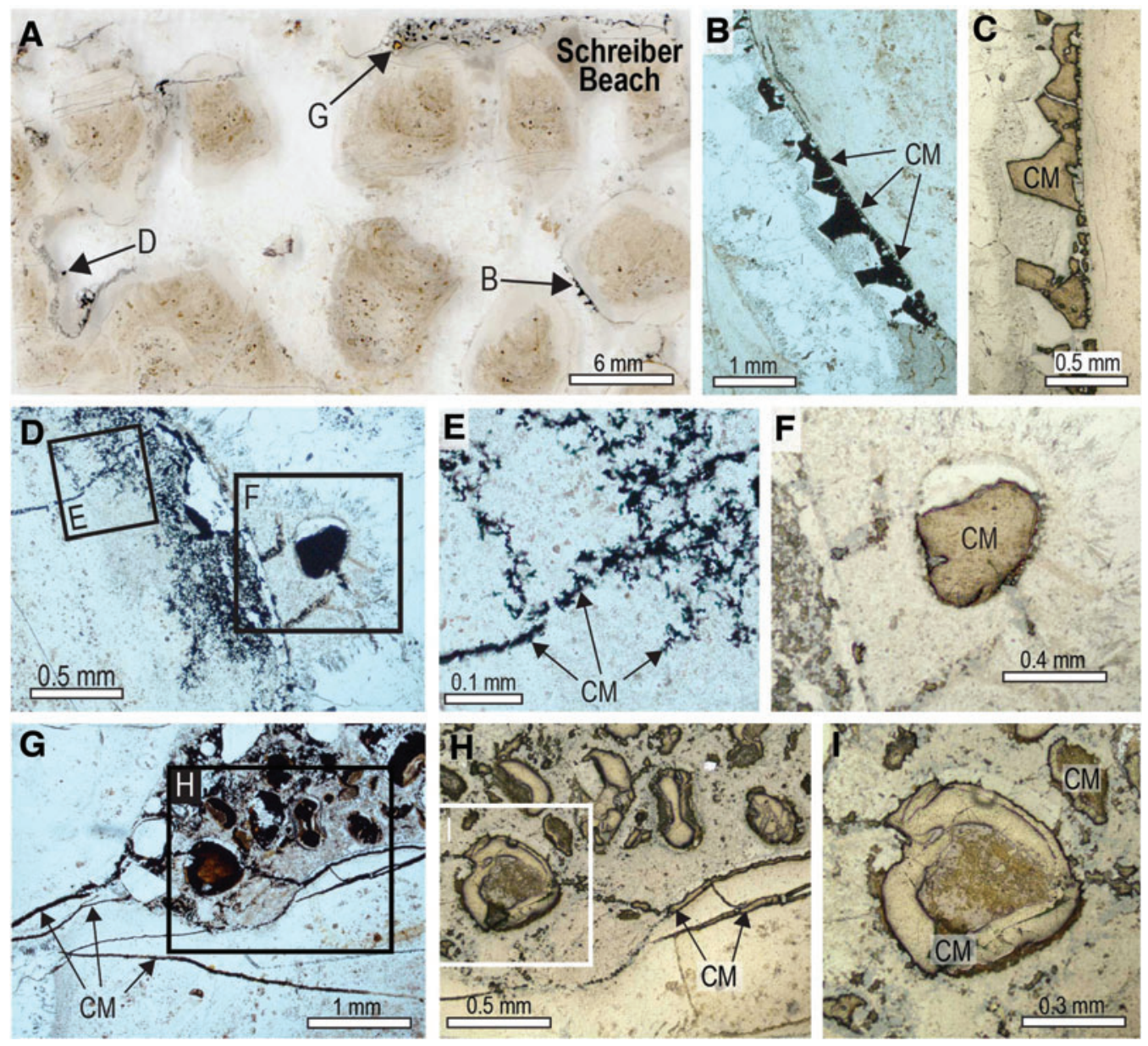

FIG. 6. Carbonaceous matter in stromatolitic chert from the Gunflint Formation at Schreiber Beach. (A) Plane polarized light (PPL) image showing carbonaceous matter (black; arrows) on surface of stromatolite columns. (B, C) PPL image (B) and reflected light (RL) image (C) of carbonaceous matter (CM). (D, E) PPL images of a network of interstitial carbonaceous matter (black) in a stromatolite column. (F) RL image of globule composed of carbonaceous matter $(\mathbf{C M})$. (G-I) PPL $(\mathrm{G})$ and RL $(\mathrm{H}, \mathrm{I})$ images of carbonaceous matter $(\mathrm{CM})$ in hairline fractures and filling intercolumn ooids. Color images are available online.

heterogeneous distribution of organic matter in the Gunflint chert. Being a liquid, oil migrating through a porous sediment will fill cavities, including interstices between particles (Fig. 14K, 14L), hollow microfossils (Fig. 14J), and in some cases, will form tiny droplets (Fig. 14I), which are only rarely preserved in the rock record (e.g., Fig. 5 in Rasmussen, 2005).

The transformation of residual oil into solid bitumen can produce carbonaceous matter that may be chemically similar to but texturally distinct from kerogen (Fig. 14) (Jacob, 1989; Alpern et al., 1992; Misch et al., 2019; Rasmussen and Muhling, 2019b). According to Jacob (1989), solid migrated oil can be recognized because it is commonly adapted to the shape of the cavities it occupies (e.g., interstices, fractures/veins, hollow microfossils, diffuse distributions). Similarly, Hackley and Cardott (2016) identified solid bitumen in thermally mature shales by its fractureoccupying, particle-enveloping and void-filling habit. Unlike kerogen, solid bitumen in matrix of organic-rich shales occurs in interstitial positions between crystal terminations of authigenic minerals. Petrographic studies of thermally mature shales indicate that the vast majority of carbona- ceous matter ( $>90 \%)$ is not kerogen, but solid bitumen representing thermally altered migrated hydrocarbons (Hackley and Cardott, 2016).

The thermal maturation of migrated oil causes devolatilization and shrinkage, converting liquid hydrocarbons into solid bitumen and eventually pyrobitumen. Pyrobitumen is an insoluble, chemically recalcitrant carbonaceous phase that is ubiquitous in postmature sedimentary rocks (Barghoorn et al., 1977; Jacob, 1989; Mancuso et al., 1989; Alpern et al., 1992; Buick et al., 1998; Rasmussen, 2005; Rasmussen et al., 2008; Melezhik et al., 2009; Bernard et al., 2012; Hackley and Cardott, 2016; Rasmussen and Muhling, 2019a). During thermal alteration, solid bitumen commonly develops nanometer-sized pores with increasing maturity (Bernard et al., 2012; Camp, 2015; Hackley and Cardott, 2016; Misch et al., 2019). The nanoporous structures, which occur in carbonaceous matter from the Gunflint stromatolitic chert and microfossils (Figs 3-5), have been attributed to exsolution of gaseous hydrocarbons from solid bitumen during thermal cracking (Bernard et al., 2012a; Bernard and Horsfield, 2014). The nanoporous structures are best developed in solid bitumen in gas mature shales 

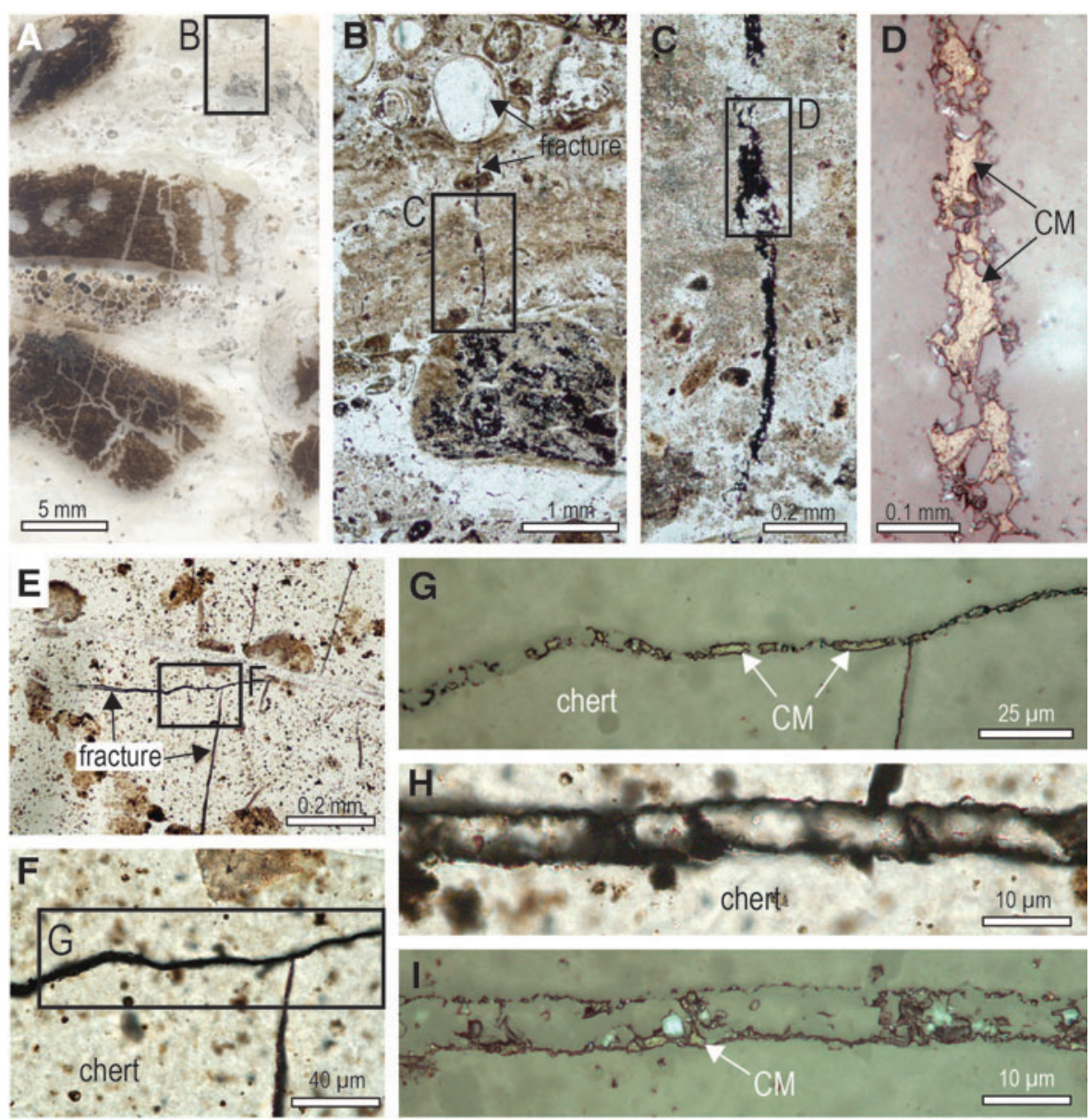

FIG. 7. Carbonaceous matter in fractures in chert from Schreiber Beach. (A-C) Plane polarized light (PPL) images of carbonaceous granule-bearing chert cross-cut by fracture filled by carbonaceous matter (black). (D) Reflected light (RL) image of carbonaceous matter (CM; brown) in fracture. $(\mathbf{E}, \mathbf{F})$ PPL images of two intersecting black fractures in chert. (G) RL image of fracture (inset in panel 7F) showing residues of carbonaceous matter (CM) filling spaces between euhedral quartz crystals. $(\mathbf{H}$, I) PPL image $(\mathrm{H})$ and $\mathrm{RL}$ image (I) of fracture lined by carbonaceous matter (CM). Color images are available online. $\left(120-150^{\circ} \mathrm{C}\right)$, temperatures that were exceeded at the Schreiber Beach locality $\left(150-170^{\circ} \mathrm{C}\right.$; Alleon et al., 2016).

\subsection{Evidence for pyrobitumen in stromatolitic chert}

Carbonaceous matter throughout the Gunflint Formation at the Schreiber Beach locality displays the shape and texture of thermally altered oil (pyrobitumen). Carbonaceous matter in fractures and diffuse haloes in the Gunflint chert (Figs. 6D-6G, 7, 10A, 10B) is clearly thermally altered relicts of migrated oil (pyrobitumen). Veins of pyrobitumen, locally known as anthraxolite, have been documented previously in the Schreiber Beach locality (Barghoorn and Tyler, 1965; Barghoorn et al., 1977). Diffuse haloes of finely dispersed carbonaceous matter around fractures and grains in the stromatolitic chert (Fig. 10), as well as in cavity-filling chalcedonic cement (Fig. 13), also implicate migrated hydrocarbons. The finely disseminated carbonaceous matter in chalcedony cements locally forms larger masses resembling pyrobitumen in carbonaceous chalcedonic rims in the 340 Ma Red Dog deposit (Fig. 1D-1G in Rasmussen and Muhling, 2019b). The presence of carbonaceous residues along the surfaces of quartz crystals in the chalcedony cement suggests that mobile hydrocarbons were present during very early diagenesis.

Likewise, solid masses of interstitial carbonaceous matter occupying the concentric lamellae of chert ooids (Figs. 2A$2 \mathrm{C}$ and $6 \mathrm{~A}-6 \mathrm{D})$ and shrinkage cavities in the chert nucleus (Figs. 2D-2F and 6A-6G) point to the migration of oil during very early diagenetic silicification. The presence of oval grains of solid pyrobitumen with concentric shrinkage structures filled by quartz (Fig. 11A-11C), and smaller curvilinear fragments (Figs. 9H-9J and 11D-11G) probably derived from the breakup of concentric pyrobitumen lamellae, indicates that oil was probably seeping into the water column during the growth of the stromatolites. This interpretation is supported by the presence of pyrobitumen in the layers of some microstromatolitic structures (Fig. 12).

\subsection{Ancient oil migration in the Gunflint Formation}

Petrographic evidence from Schreiber Beach for the ancient migration of hydrocarbons (e.g., Barghoorn and Tyler, 1965; Barghoorn et al., 1977; Rasmussen and Muhling, 2019a; this study) is supported by observations of solidified oil in the Gunflint Formation from other localities (Goodwin, 1956; Barghoorn et al., 1977; Mancuso et al., 1989; Rasmussen and Muhling, 2019a). For instance, Goodwin (1956), reports the presence of anthraxolite at multiple stratigraphic levels of the Gunflint Formation from numerous localities in the Thunder Bay area. Barghoorn et al. (1977) described anthraxolite with conchoidal fracture in lenses up to $3 \mathrm{~cm}$ wide in chert from the Gunflint Formation east of Thunder Bay $\left(\delta^{13} \mathrm{C} 37.0 \pm 0.1 \%\right.$ ) and Schreiber Beach $\left(\delta^{13} \mathrm{C} 39.2 \pm 0.1 \%\right)$. They argued that the anthraxolite probably "originated as a petroleum or crude oil complex which migrated as liquid into fractures and sedimentary 

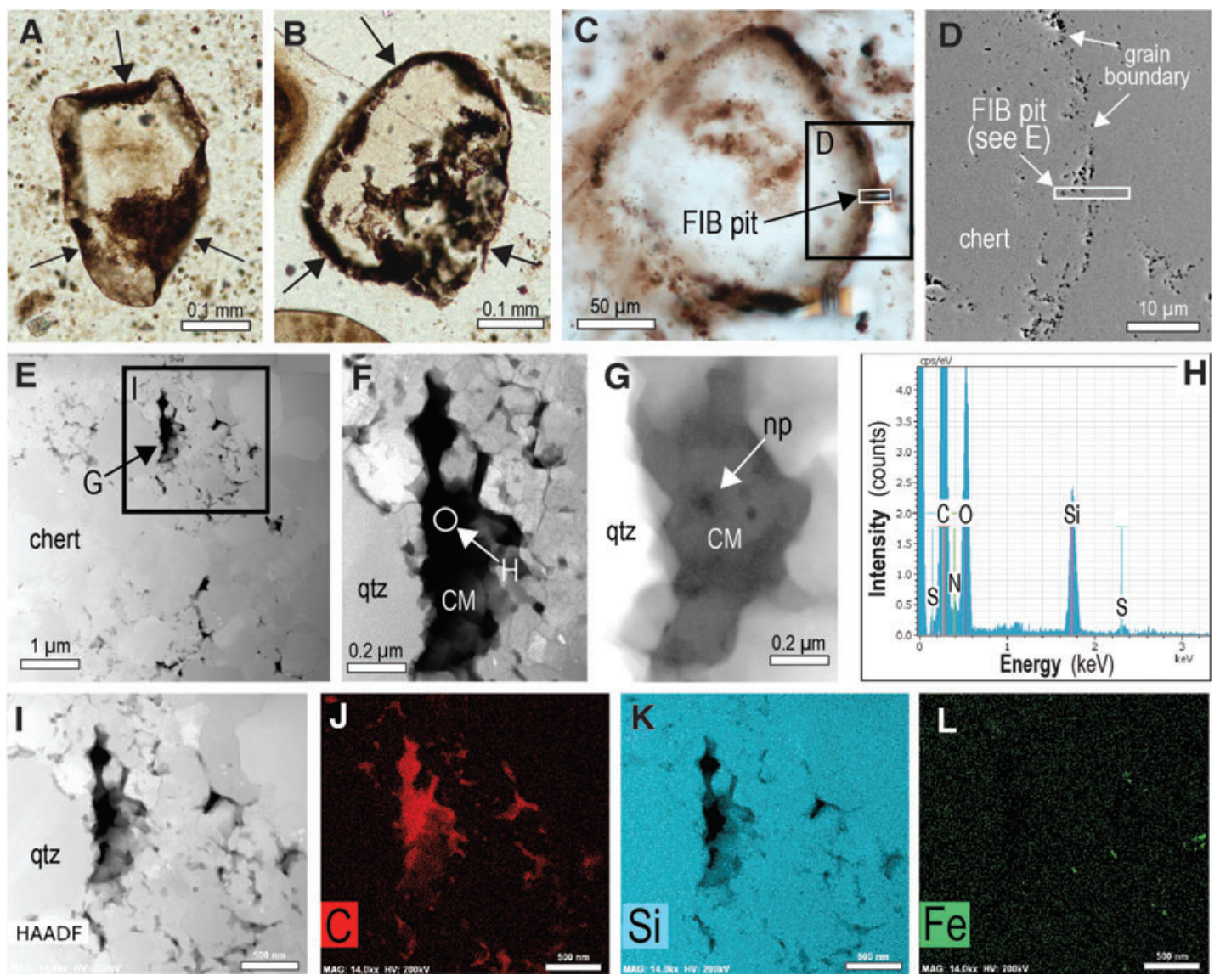

FIG. 8. Carbonaceous matter lining chert grains from the Gunflint Formation, Schreiber Beach. (A-C) Plane polarized light (PPL) images of detrital chert grains lined by a carbonaceous film (see arrows). (D) Scanning electron microscope photo of boundary between detrital chert grain and chert matrix in (C) showing location of FIB traverse. (E-G, I) STEM dark-field images of interstitial carbonaceous matter (black) in TEM foil extracted from (C), (E). (H) TEM-EDS spectra acquired from carbonaceous matter (see 8F) lining detrital chert grain. (J-L) TEM-EDS element maps for carbonaceous matter in $(\mathrm{I})$, including carbon $(\mathrm{J})$, silicon $(\mathrm{K})$, and iron $(\mathrm{L})$. Color images are available online.

bedding planes where it polymerized in situ forming a solid, secondarily emplaced constituent of the sediment."

Mancuso et al. (1989) identified pyrobitumen $\left(\delta^{13} \mathrm{C}\right.$ $33.2 \pm 0.2 \%$ o in calcite veins up to $15 \mathrm{~cm}$ wide crosscutting black chert of the Gunflint Formation at Kakabeka Falls. More recently, Rasmussen and Muhling (2019a) identified pyrobitumen throughout iron formations of the Gunflint Formation in drill hole 89-MC-1. Petrographic textures indicated at least two phases of oil migration, an earlier episode overlapping with sedimentation and very early silica diagenesis and a later episode postdating lithification (Rasmussen and Muhling, 2019a).

\subsection{Origin of carbonaceous matter in microfossils}

The possibility that the carbonaceous Gunflint microfossils were "produced by condensation or polymerization of material which entered the chert prior to crystallization of the chalcedonic matrix" was briefly raised by Barghoorn and Tyler (1965). However, this scenario was dismissed in preference for an indigenous origin, in which the carbon within microfossils was interpreted to be altered remnants of the original cellular material. Since then, organic carbon in the Gunflint stromatolitic black cherts has generally been interpreted as relicts of thermally altered cellular material and widely referred to as kerogen. Although microbial cells are rapidly destroyed after death, it is thought that limited microbial decomposition under anaerobic conditions combined with early and rapid mineralization by dissolved silica can enhance the preservation of organic cellular material.

To understand how organically preserved microfossils formed in ancient chert, studies have been carried out on silica-rich thermal spring deposits. High-resolution microscopy of geysers has shown that dissolved silica readily nucleates on substrates, including those of microbes, encrusting surfaces and filling cavities. While the morphology of the microbes is preserved, the organic cellular contents appear to undergo rapid degradation forming hollow molds. In their petrographic study of thermal springs in Yellowstone National Park, Cady and Farmer (1996) noted that "organically preserved filaments have not yet been observed" from Phormidium-type sinters from Artist Point $(0.07 \mathrm{Ma})$. Instead, cellular materials from the interior of filament molds "appear to have been removed by decay or autolysis following encrustation." Petrographic examination of sub-Recent Calothrix-type sinters ( $\sim 3 \mathrm{Ma})$ from McGinness Hills, Nevada, did not reveal organically preserved sheath materials but revealed palisade frameworks 

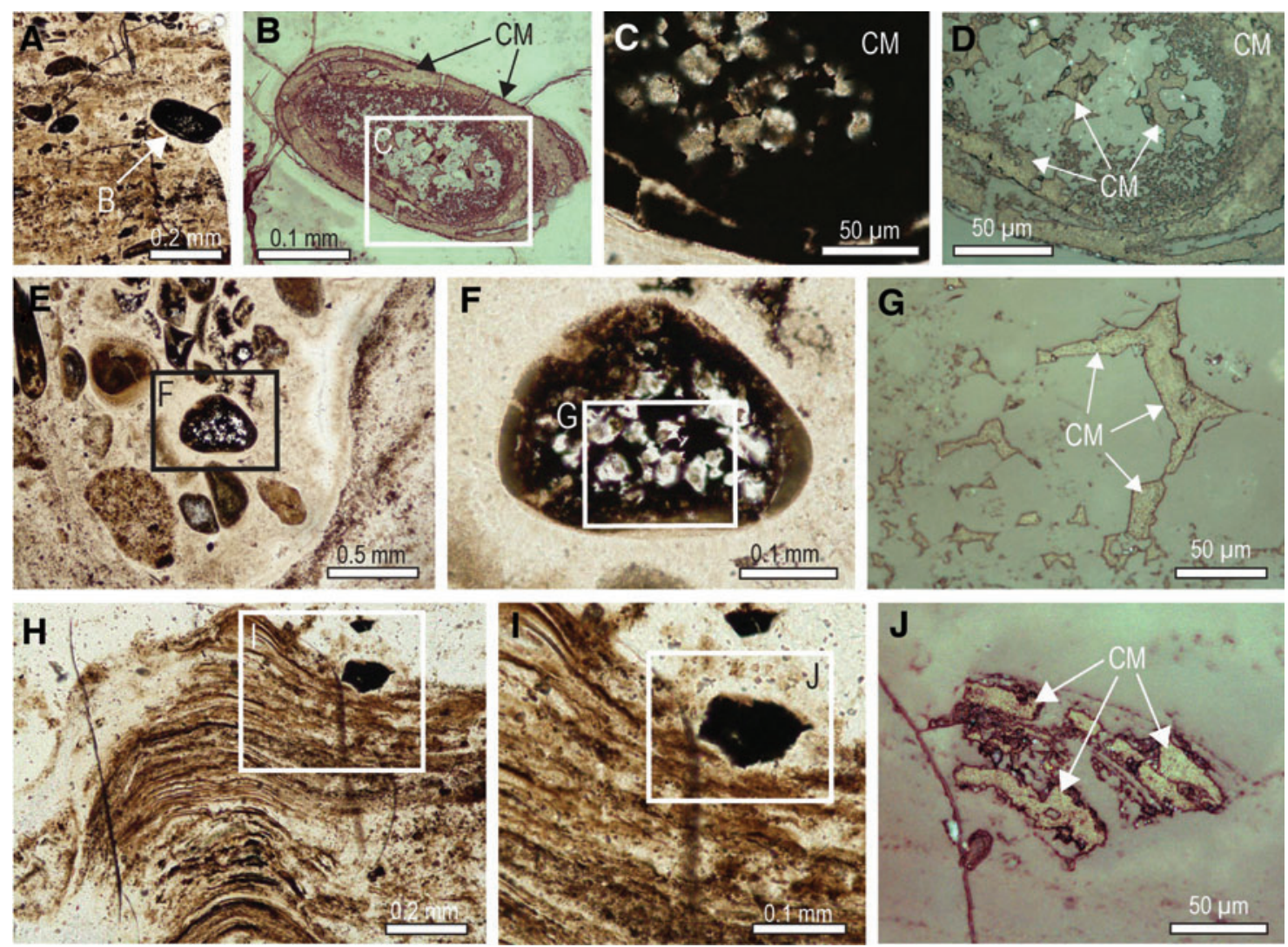

FIG. 9. Carbonaceous matter in ooids in stromatolitic chert, Schreiber Beach. (A-D) Plane polarized light (PPL) images $(A, C)$ and reflected light $(\mathrm{RL})$ images $(\mathrm{B}, \mathrm{D})$ of ooid with carbonaceous matter $(\mathrm{CM})$ in oolitic outer skins and in shrinkage cavities between quartz crystals. (E-G) PPL images (E, F) and RL image (G) of chert ooid with interstitial carbonaceous matter (CM) in polygonal shrinkage structures. (H-J) PPL images (H, I) and RL image (J) of angular grain composed of carbonaceous matter $(\mathrm{CM})$ enclosed in finely laminated stromatolitic structure. Color images are available online.

containing abundant filament-shaped molds infilled by secondary silica (Cady and Farmer, 1996). While filament molds are preserved in most sub-Recent geyser pools and channels, organic preservation is generally poor (Cady and Farmer, 1996).

The observations from geysers pointing to rapid degradation of cellular material receive support from a study of carbonaceous microfossils in chert from the 340 Ma Red Dog hydrothermal $\mathrm{Zn}-\mathrm{Pb}$ deposit, Alaska (Rasmussen and Muhling, 2019b). The sulfide deposit formed by hydrothermal replacement of carbonaceous and calcareous sediments and venting onto the seafloor (Edgerton, 1997; Leach et al., 2004; Slack et al., 2015). Silica precipitation and hydrocarbon migration were coeval with hydrothermal sulfide mineralization.

Within the sulfide deposit are chert pebbles that contain intertwined carbonaceous microfossils, which closely resemble filaments from the Gunflint Formation. The carbonrich filaments are restricted to the immediate vicinity of bitumen-lined fractures that crosscut the chert. The carbon content of the filaments decreases sharply away from the bituminous fractures and quickly becomes near-invisible along their length (Fig. 2H, 2I in Rasmussen and Muhling, 2019b). The carbonaceous matter in the filaments adjacent to fractures occurs as $\sim 50 \mathrm{~nm}$ thick films lining minute quartz crystals that fill the intracellular cavities. The intracellular carbon is interpreted to have entered the filamentous microfossils after decay of cellular material and growth of quartz via a process involving diffuse infiltration of oil moving along fractures (Rasmussen and Muhling, 2019b).

The amount of carbon in filaments distal to fractures is significantly lower, rendering the microfossils nearinvisible. The lack of carbon in the distal filaments, except for relicts lining quartz (Fig. 4 in Rasmussen and Muhling, 2019b), suggests that most of the original cellular carbon in the microfossils was destroyed.

Our observations reveal multiple lines of evidence to suggest that migrated hydrocarbons also played a role in the formation of the carbonaceous microfossils at Schreiber Beach. These include the following:

(1) The widespread distribution of pyrobitumen throughout the stromatolitic chert at Schreiber Beach (e.g., fractures, interstices, coatings, chalcedonic cement) (Figs. 2, 6-13);

(2) The infiltration of hydrocarbons (now pyrobitumen) along laminae of micro-stromatolitic structures (Fig. 12);

(3) The uniform optical properties and chemical composition of organic matter in microfossils and pyrobitumen in the stromatolitic chert and intercolumn sediments;

(4) The presence of nanopores in carbonaceous matter within microfossils (Figs. 3-5) (Fig. 1B, Supp. Figs. 4A, 6, 11B, 11C, and 12B in Lepot et al., 2017), 

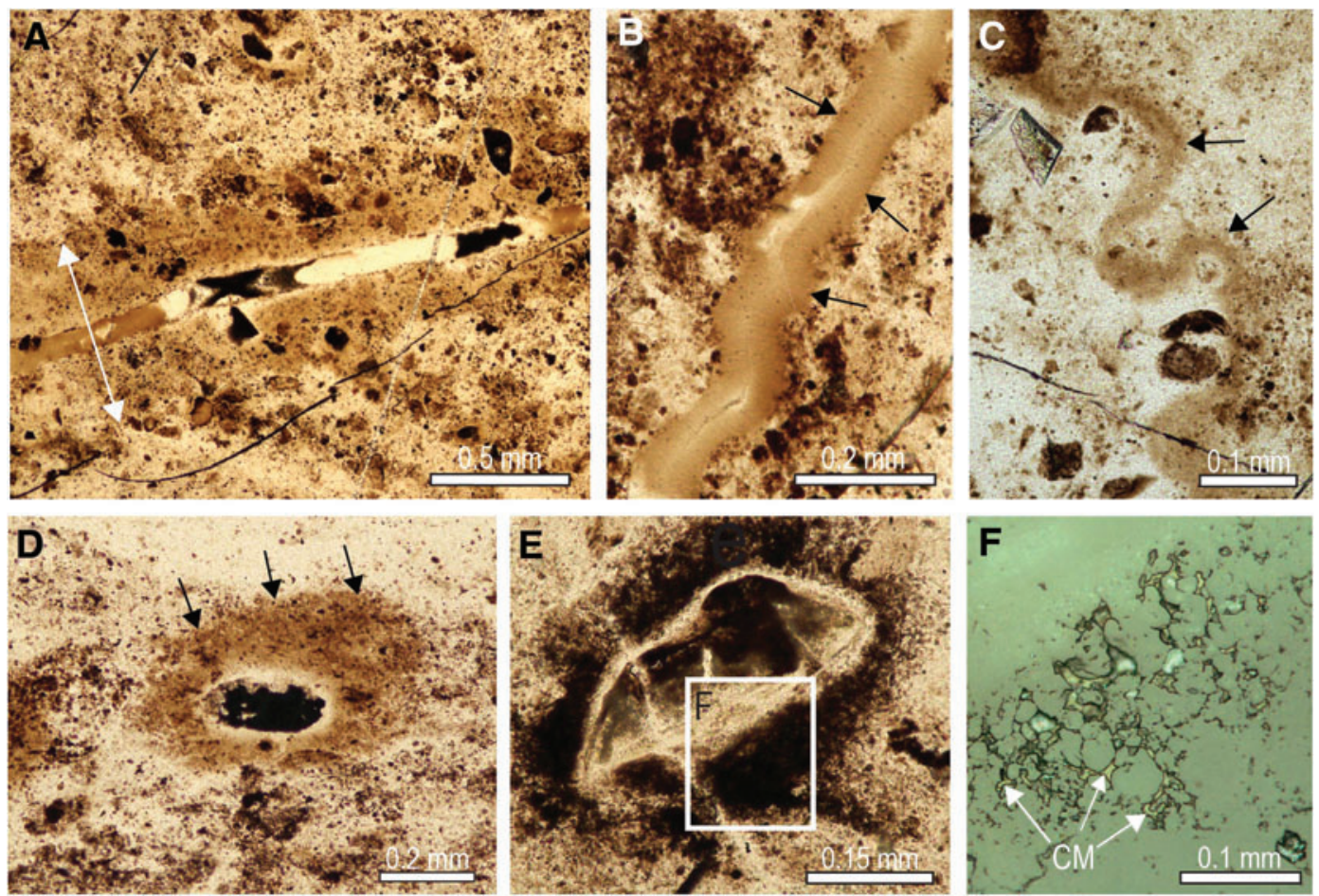

FIG. 10. Carbonaceous matter in fractures and diffuse haloes, Schreiber Beach. (A, B) Plane polarized light (PPL) images of cross-cutting fracture filled by brown-stained chalcedony and locally surrounded by diffuse carbonaceous halo (see arrows). (C) PPL image of discordant brown band of carbonaceous matter (see arrows) in stromatolites. (D, E) PPL images of light brown to black haloes of carbonaceous matter (see arrows in D) around chert grains in stromatolitic chert. (F) Reflected light image of black rim in (E) showing presence of interstitial carbonaceous matter (CM) between quartz crystals. Color images are available online.

a structure commonly developed in thermally altered oil (solid bitumen) (Bernard et al., 2012; Camp, 2015; Hackley and Cardott, 2016; Misch et al., 2019);

(5) The presence of authigenic minerals (e.g., greenalite) in carbonaceous matter within microfossils (Fig. 4), a feature associated with the entrainment of clay particles by oil in younger thermally altered shales (Misch et al., 2019);

(6) The strong resemblance of carbon K-edge synchrotron absorption spectra (C-XANES) from the carbonaceous microfossils with spectra from bitumen in post-oil shales (Bernard et al., 2012);

(7) The presence of nanometer-sized inclusions of carbonaceous matter in quartz euhedra (Fig. 5), indicating two or more generations of carbonaceous matter within some microfossils (pre- and post-quartz euhedra).

Collectively, these lines of evidence suggest that the black stromatolitic cherts of the Gunflint Formation at Schreiber Beach do not contain exclusively indigenous carbonaceous matter (i.e., kerogen) but secondary migrated hydrocarbons that infiltrated the siliceous stromatolites during growth. When combined with evidence for the lack of organic preservation of microbes in modern and ancient silica-rich hydrothermal systems (Schultze-Lam et al., 1995; Cady and Farmer, 1996; Westall, 1999; Jones et al., 2001; Konhauser et al., 2001; Lynne and Campbell, 2003; Gong et al., 2020), secondary carbon in the form of oil has to be considered as a source of at least some of the carbon filling the Gunflint microfossils. Indeed, this fossilization mechanism has been documented in the $340 \mathrm{Ma}$ Red Dog $\mathrm{Zn}-\mathrm{Pb}$ deposit, where carbonaceous microfossils are interpreted to have formed by oil diffusion into intracellular cavities adjacent to bituminous fractures in chert (Rasmussen and Muhling, 2019b).

While the possibility that some of the carbon in the Gunflint microfossils is indigenous cannot be excluded, nor can the possibility that some of the carbon is derived from migrated hydrocarbons. Our observations lead us to propose a scenario involving the syn-sedimentary silicification of microbial cell walls or sheaths and the partial to complete decomposition of the cellular organic remains. High concentrations of dissolved $\mathrm{SiO}_{2}$ are indicated by the abundance of chert intraclasts and ooids in intercolumn sediments in the Gunflint stromatolites. Microbial cell walls in the stromatolites acted as nucleation sites for silica molecules, whereby hydrogen bonding attached functional groups in microbial walls to polysilicic acid. The initiation of nucleation would have acted to accelerate cementation by silicic acid polymerization. Decomposition of the original organic molecules led to the development of silica-entombed molds, as observed in silicification experiments of bacteria (Westall et al., 1995) and in terrestrial hydrothermal spring deposits (Cady and Farmer, 1996; Gong et al., 2020). The filamentous and spherical molds were infiltrated by synsedimentary hydrocarbons which halted the occlusion of the cellular cavities by silica cementation. During heating, 

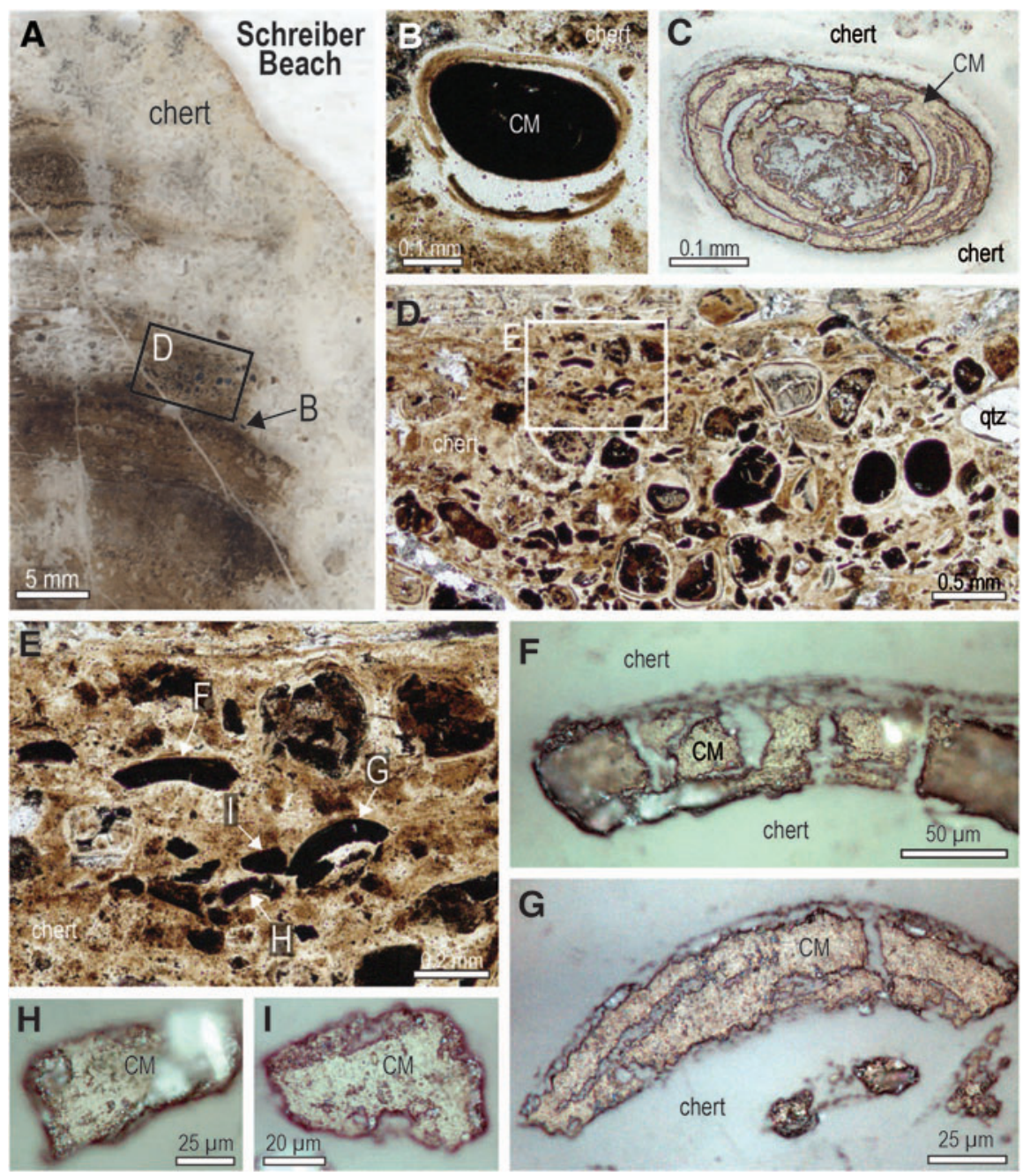

FIG. 11. Detrital grains of carbonaceous matter in stromatolitic chert, Schreiber Beach. (A) Plane polarized light (PPL) image of grains composed of carbonaceous matter (black) in chert. (B) PPL image of oval grain composed of carbonaceous matter (CM). (C) Reflected light (RL) image of grain composed of $\mathrm{CM}$ with concentric shrinkage structures filled by quartz. (D, E) PPL images of carbonaceous granular chert (brown) with clasts of solid carbonaceous matter (black). (F-I) RL images of carbonaceous clasts (CM) whose curvilinear shapes resemble the coatings of the concentric carbonaceous grain in $(\mathrm{C})$. Color images are available online. the liquid hydrocarbons were converted to solid carbonrich masses of pyrobitumen with a nanoporous structure (Figs. 3D-3G, 4A, 4B).

\subsection{Carbonaceous matter and the retardation of silica growth}

A relationship between the distribution of carbonaceous matter, quartz growth, and preservation of microfossils was noted by Barghoorn and Tyler (1965): "These constituents, particularly the organic matter, have exerted a strong influence upon the texture of the rock, for there is a close correlation between the grain size of chalcedony and quartz and the abundance of finely disseminated organic matter. The organic matter has had a profound effect on inhibiting grain growth."

Observations from fossiliferous chert from the $340 \mathrm{Ma}$ Red Dog deposit suggests that the infiltration of hydrocarbons along fractures and into semi-hollow filamentous microfossils inhibited the growth of silica relative to filaments distal to the bituminous fractures (Figs. 3 and 4 in Rasmussen and Muhling, 2019a). Microbial filaments outside the carbon-rich haloes around the fractures contain more silica, less carbonaceous matter, and smaller cavities.

The migration and accumulation of oil in reservoir sandstones is known to inhibit diagenesis and porosity destruc- tion in paleo-oil columns. For instance, in the reservoir sandstones from the northern Perth Basin, Western Australia, sandstones above the oil-water contact (OWC) contain significantly less authigenic quartz cement and preserve high porosities relative to sandstones below the OWC (Fig. 13 in Rasmussen and Glover, 1996).

It is feasible that the introduction of fluid hydrocarbons into siliceous microbial molds may have played a role in enhancing the preservation of the Gunflint microfossils by retarding silica cementation and grain coarsening during recrystallization. The mechanism is unclear, but carbonaceous matter occupying cavities or lining quartz crystals may have hampered the nucleation of dissolved silica onto the crystal surfaces and the coarsening of grains during recrystallization.

\subsection{Syn-sedimentary oil migration and seafloor hydrocarbon seep}

The presence of detrital fragments of pyrobitumen (solidified oil) in the 1.90-1.85 Ga Gunflint Formation (Fig. 11) suggests that the onset of oil migration overlapped with the 1.86-1.80 Ga Penokean orogeny (Rasmussen and Muhling, 2019a). As in younger analogs, tectonic loading and heating of source rocks in pre-foreland basin shales may have led to hydrocarbon generation and migration outward and updip into the sediments of the Gunflint Formation. The Archean 
FIG. 12. (A) Image of laminated domal chert containing ooids. (B, C) Plane polarized light (PPL) images of carbonaceous chert featuring two ooids. (D, E) PPL images of microstromatolitic structures delineated by carbonaceous matter (brown and black). (F) Reflected light (RL) image of interstitial carbonaceous matter (CM) in laminae of microstromatolite. $(\mathbf{G}, \mathbf{H})$ PPL images of micro-stromatolitic structures in carbonaceous chert. (I) RL image of $\mathrm{CM}$ in cavities along laminae in microstromatolite (see panel $12 \mathrm{H}$ ). (J) Image of laminated carbonaceous chert. (K, L) PPL images of micro-stromatolitic columns. (M) $\mathrm{RL}$ image showing $\mathrm{CM}$ between quartz crystals in core of microstromatolite. Color images are available online.
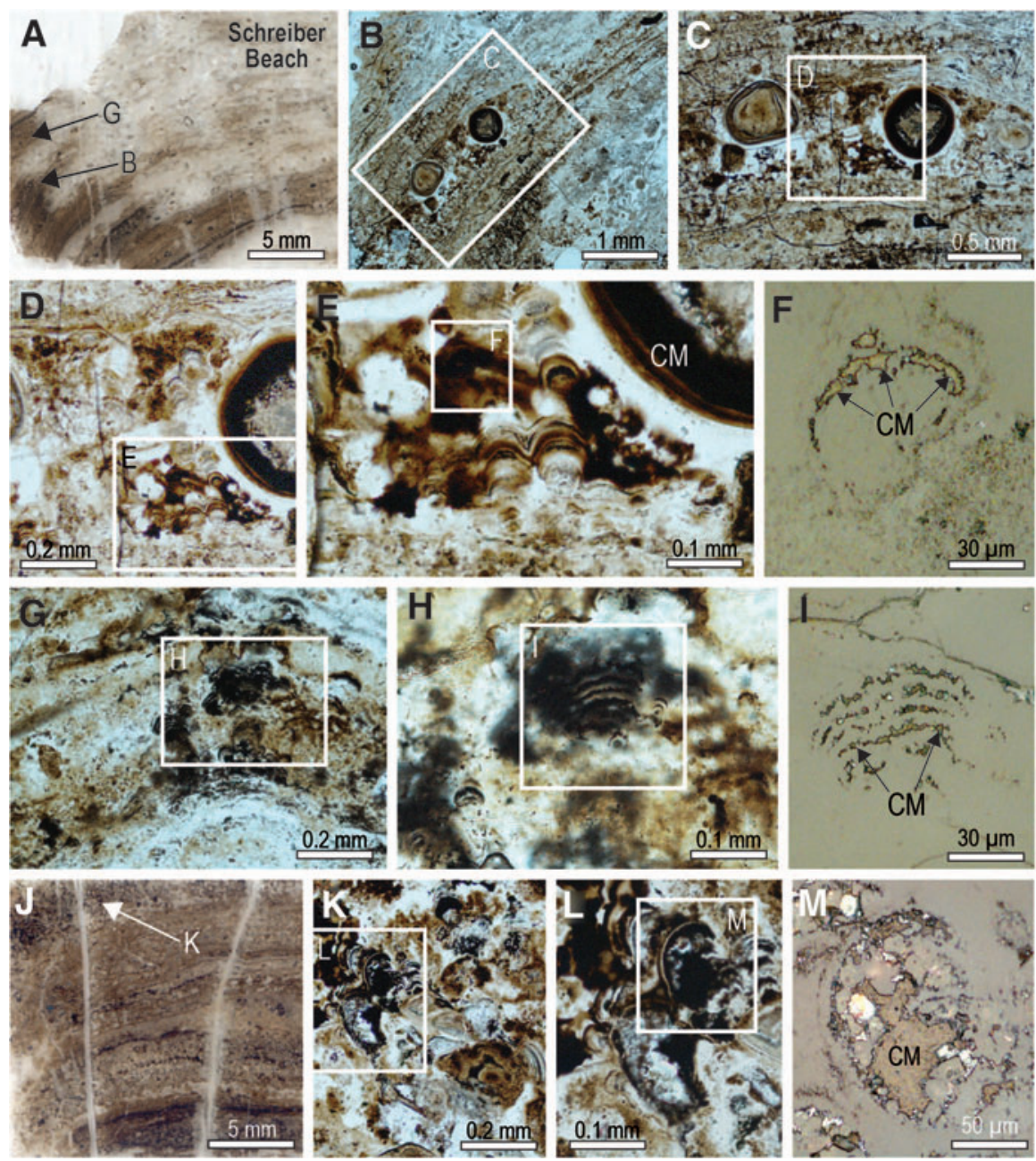

igneous basement below the Gunflint Formation between the Thunder Bay area and Schreiber Beach would have acted as an impermeable barrier, focusing upward migrating hydrocarbons along the unconformity surface and into overlying sediments. The deposition of clastic grains of solidi-

fied oil in the Gunflint stromatolites suggests that oil seeped into the overlying water column. The occurrence of solid bitumen ooids and exfoliated fragments implies that the oil was rapidly degraded, transported, and redeposited (Melezhik et al., 2009).
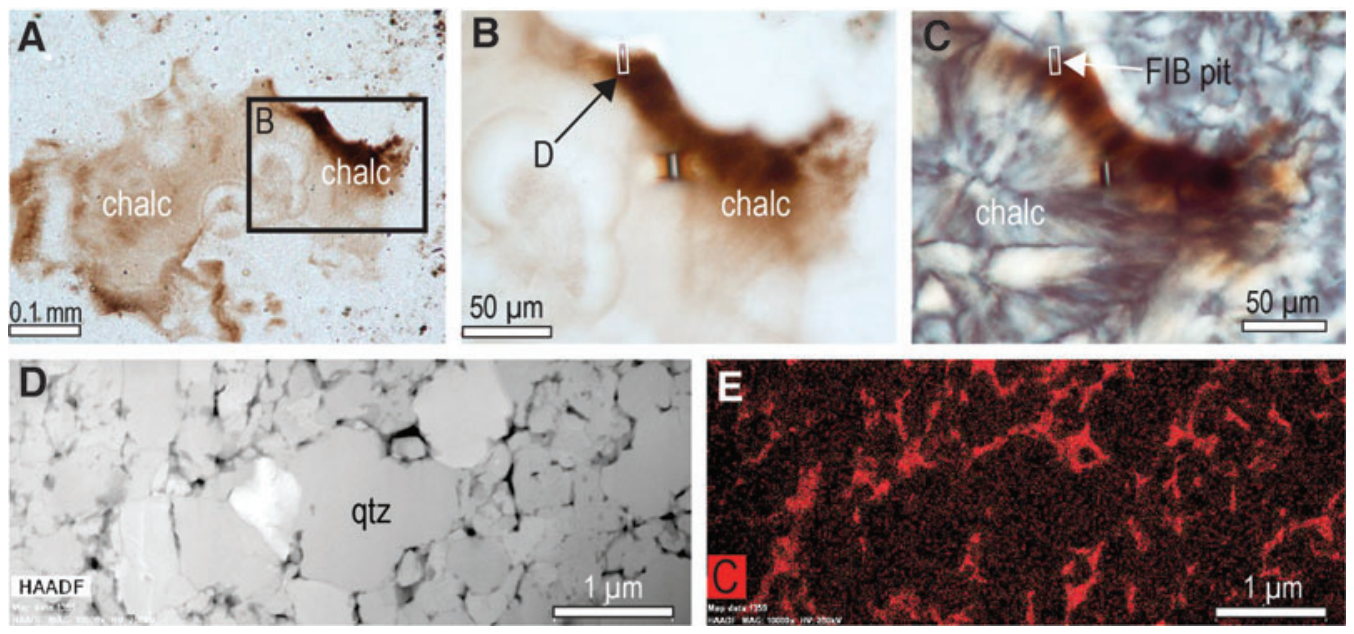

FIG. 13. Composition of brown pigment in diagenetic chalcedony. (A-C) PPL images (A, B) and cross-polarized light (XPL) image (C) of brown-stained chalcedony fans showing location of two FIB traverses (arrows). (D) STEM dark-field image of micro-quartz crystals in chalcedony fans. (E) TEM-EDS carbon (C) map showing irregular-shaped masses of carbonaceous matter along quartz grain boundaries. Color images are available online. 

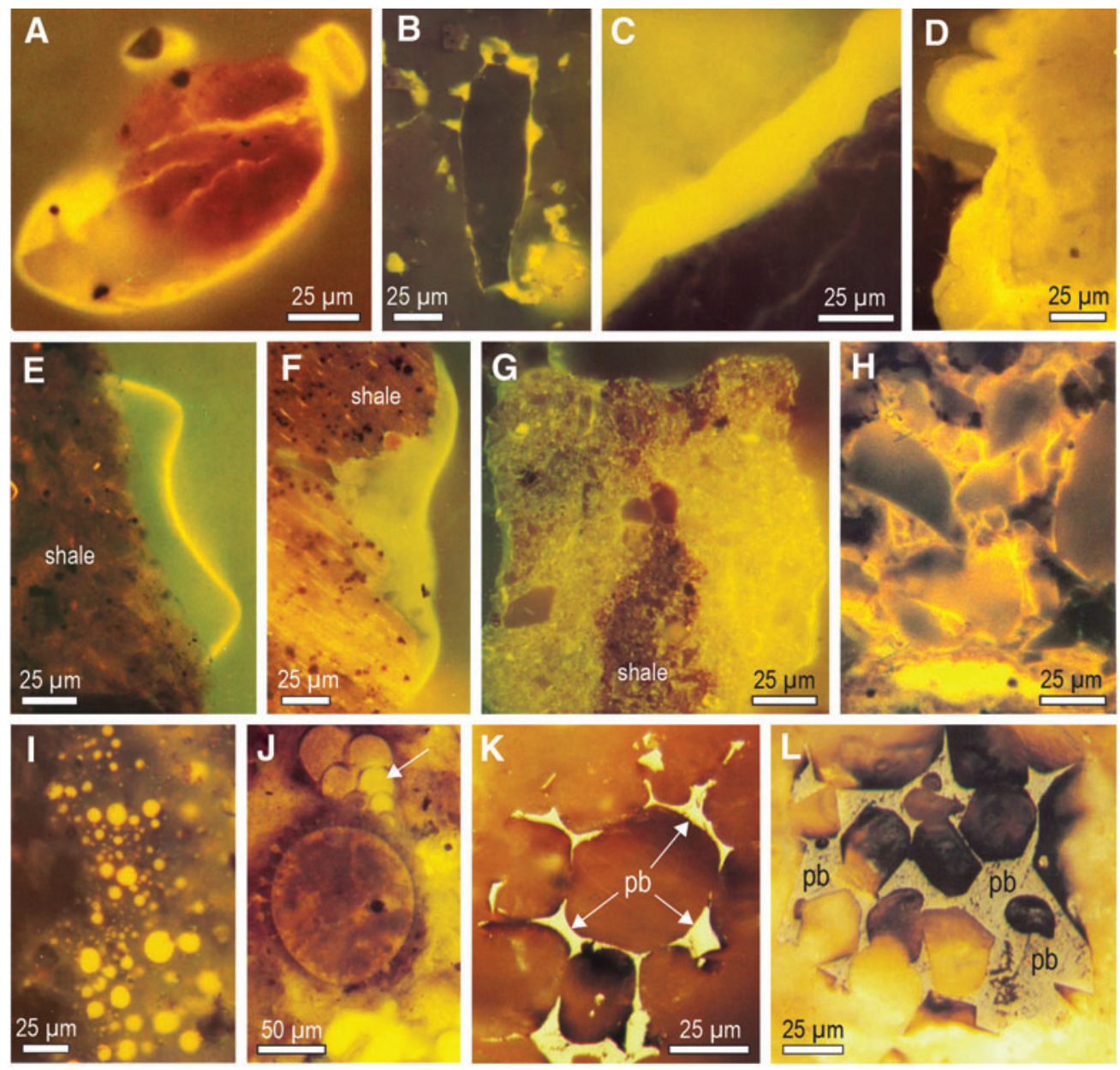

FIG. 14. Ultraviolet fluorescent light (UV-FL) images of oil and bitumen from Phanerozoic petroliferous basins. (A) UV-FL image of shale fragment covered in bright yellow fluorescing oil film. Drill-hole cuttings, 6670-6690', Angola. (B) UV-FL image of elongate grain surrounded by irregular coating of oil (bright yellow). Drill-hole cuttings, 2520-2550', Angola. (C) UV-FL image of thick yellow film of oil covering nonfluorescent shale. Drill-hole cuttings, 9650-9670', Angola. (D) UV-FL image of wavy yellow fluorescent oil coating matrix. Drill-hole cuttings, 5750', Papua New Guinea. (E, F) UV-FL images of oil film (bright yellow) on surface (E) and in matrix of shale (F). (E) Drill-hole cuttings, 8200', Papua New Guinea; (F) drillhole cuttings, 7740-7770', India. (G) UV-FL image of shale matrix saturated in oil (bright yellow). Drill-hole cuttings, 7000', Colombia. (H) UV-FL image of oil (bright yellow) lining mineral surfaces in a shale matrix. Drill-hole cuttings, 10810-10840', Zaire. (I) UV-FL image of oil droplets (bright yellow) in nonfluorescent shale matrix. Drill-hole cuttings, 14320-14330', Angola. (J) UV-FL image of oil (yellow) filling cavities in microfossils (see arrow). Drill-hole cuttings, 1560-1590', Turkey. $(\mathbf{K}, \mathbf{L})$ Reflected light (RL) images of light gray pyrobitumen (pb) filling interstitial cavities between euhedral crystals. (K) Drill-hole cuttings, 7890', Papua New Guinea; (L) drill-hole cuttings, 8010-8020', Papua New Guinea. Images from Alpern et al. (1992), reproduced with permission from A.G. Dias, Universidade do Porto. Color images are available online.

Because hydrocarbon-fueled chemosynthetic ecosystems are characteristic of modern oil seeps (Jørgensen and Boetius, 2007) and shallow oil reservoirs (Head et al., 2003), it is possible that the Gunflint microbial community included microbes whose metabolisms were tied to the degradation of hydrocarbons and bacterial sulfate reduction. Indeed, the presence of sulfate-reducing microbes has been inferred from the sulfur-isotopic composition of pyritized microfossils in the Gunflint stromatolites (Wacey et al., 2013).

\subsection{Implications for Precambrian paleobiology}

The abundance of carbonaceous matter in the Gunflint microfossils has led to the general view that relicts of original cellular carbon are important, if not essential, for putative microfossils to be accepted as bona fide biosignatures (Buick, 1990; Schopf et al., 2002, 2005; McLoughlin and Grosch, 2015). The possibility that carbonaceous matter in ancient rocks and microfossils could be derived from, or contaminated by, organic compounds introduced after deposition has been acknowledged (Brasier et al., 2002; García-Ruiz et al., 2003; Lindsay et al., 2005; Lepot et al., 2009; Oehler et al., 2009; Oehler and Cady, 2014). While organic contaminants seem to be the most likely source of soluble hydrocarbon biomarkers extracted from organic-rich shales from the Pilbara and Kaapvaal cratons (Rasmussen et al., 2008; Brocks, 2011; French et al., 2013, 2015), a non-indigenous origin for carbonaceous matter in Precambrian microfossils is generally discounted. 
Although organic-coated microstructures, which resemble early Precambrian microfossils, have been synthesized (e.g., García-Ruiz et al., 2003), they lack intracellular carbonaceous matter (Schopf et al., 2005). In particular, the one-forone spatial correlation between biological morphology and thermally altered carbonaceous matter is regarded as a characteristic attribute of bona fide microfossils (Schopf et al., 2005).

Our observations from Schreiber Beach show that liquid hydrocarbons seeped through the silicifying Gunflint stromatolites. If the hydrocarbons infiltrated intracellular hollows of silicified microbes, they could plausibly produce microfossils containing pyrobitumen whose distribution mimics indigenous cellular carbonaceous matter. Indeed, this process appears to be responsible for the formation of carbonaceous filaments in chert from the $340 \mathrm{Ma}$ Red Dog deposit, Alaska (Rasmussen and Muhling, 2019b).

An important implication of these results is that while the organic phase in microfossils can be biogenic it is not necessarily indigenous. It follows that the chemistry of the organic carbon in a microfossil (e.g., H/C, N/C, and $\delta^{13} \mathrm{C}$ ratios; House et al., 2000; Williford et al., 2013) does not necessarily reflect the composition of the original microorganism.

Because the biogenicity of the Gunflint microfossils is not in dispute, our results imply that the lack of indigenous carbon should not preclude a biological interpretation for putative microfossils. However, the migration of hydrocarbons through ancient sediments can potentially produce carbon-coated or carbon-filled microstructures that mimic the shape of simple life-pseudofossils. Hence, the mere presence of carbonaceous matter in microstructures resembling putative microfossils is not definitive evidence that the structures are biological. Indeed, the migration of nonindigenous, carbon-bearing fluids has been suggested previously as a potential source of carbonaceous matter in ancient "microfossils" (Brasier et al., 2002; García-Ruiz et al., 2003; Wacey et al., 2016) or microfossil-like structures (Lepot et al., 2009).

Ancient hydrocarbon generation, either via thermal maturation of organic-rich shales or Fischer-Tropsch-type synthesis reactions, was probably not uncommon on early Earth. Indeed, there is widespread evidence for hydrocarbon migration in Archean cherts (Rasmussen and Buick, 2000; van Zuilen et al., 2007; Knoll, 2012; Marshall et al., 2012; Sforna et al., 2014), raising the possibility that mobile carbon-rich compounds played a role in the formation of some of Earth's oldest microfossils (and pseudofossils).

\section{Conclusions}

Our results show that stromatolitic black cherts from the Gunflint Formation were infiltrated by ancient oil. The textural relationships, including the presence of detrital bitumen ooids and clasts, indicate that oil migration commenced during growth of the stromatolites and that oil seeped into the water column. The presence of residual oil (pyrobitumen) coating inorganic grains and lining diagenetic mineral surfaces implies that some of the carbonaceous matter lining and/or filling the Gunflint microfossils may have a similar origin. This is supported by multiple lines of evidence, including the presence of nanoporous carbonaceous matter between intracellular quartz crystals, widely linked to the thermal alteration of migrated oil. Our observations suggest a scenario in which the silicification of microorganisms produced semi-hollow molds encased in silica that were infiltrated by migrating hydrocarbons, producing microfossils with carbon-rich interiors and/or rims. Because oil generation is likely to have operated as early as 3.5 billion years ago, hydrocarbon migration into semisilicified, microbial molds may have played a role in the formation of ancient carbonaceous microfossils. The migration of oil through the Gunflint stromatolites and seepage into the water column suggest that the microbial community included hydrocarbon-fueled chemosynthetic microbes.

\section{Appendix A. Methods}

Lamellae for TEM analyses were cut from carbon-coated polished thin sections of black stromatolitic chert containing abundant filamentous and spherical microfossils. FIB techniques were used to prepare $\sim 100 \mathrm{~nm}$ thick TEM lamellae ( $\sim 10 \mu \mathrm{m}$ by $5 \mu \mathrm{m}$ ) using an FEI Helios NanoLab G3 CX DualBeam instrument located at the Centre for Microscopy, Characterisation and Analysis (CMCA), The University of Western Australia (UWA). A $2 \mu \mathrm{m}$ thick strip of Pt was deposited on the areas selected for TEM analysis by using a $\mathrm{Ga}$ ion beam with $30 \mathrm{kV}$ voltage and $0.43 \mathrm{nA}$ current. Trenches $7-8 \mu \mathrm{m}$ deep were milled on either side of the strip by using a regular cross-section and the $\mathrm{Ga}$ ion beam at $30 \mathrm{kV}$ voltage and $9.3 \mathrm{nA}$ current. Surfaces were cleaned by using a cleaning cross-section at $30 \mathrm{kV}$ and $2.5 \mathrm{nA}$. The lamellae were then cut away from the samples and welded to $\mathrm{Cu}$ TEM grids. The lamellae were thinned with the $\mathrm{Ga}$ ion beam at $30 \mathrm{kV}$ and $0.79 \mathrm{nA}$ and $0.23 \mathrm{nA}$, before cleaning at $5 \mathrm{kV}$ and $41 \mathrm{pA}$, and polishing at $2 \mathrm{kV}$ and $23 \mathrm{pA}$.

TEM data were obtained at $200 \mathrm{kV}$ with an FEI Titan G2 80-200 TEM/STEM and ChemiSTEM technology located at CMCA, UWA. Bright-field TEM and STEM, highresolution transmission electron microscopy (HRTEM) and HAADF STEM images were collected and processed with TIA (TEM Imaging and Analysis) software from FEI and Digital Micrograph from Gatan Incorporated. Qualitative EDS spectra and hypermaps were collected by using the Super X detector on the Titan with a probe size of $\sim 1 \mathrm{~nm}$ and a probe current of $\sim 0.9 \mathrm{nA}$ and were processed with Bruker Esprit software.

\section{Acknowledgments}

The authors acknowledge support from Australian Research Council grants DP140100512 (B.R.) and DP190102237 (B.R. and J.R.M.), and Simons Foundation Collaboration on the Origins of Life (W.W.F.). SEM, FIB, and TEM analyses were performed at CMCA at UWA, a node of Microscopy Australia funded from university and government sources, and we thank A. Suvorova, S. Gain, and M. Saunders for technical support. We thank S. Sheppard and B. Krapez for their assistance in the field, and A.G. Dias and M.J. Lemos de Sousa (Geociências, Ambiente e Ordenamento do Território, Faculdade de Ciências da Universidade do Porto) for permission to reproduce images from Alpern et al. (1992). We thank four anonymous reviewers and the associate editor for their comments that helped improve the manuscript. 


\section{Author Disclosure Statement}

No competing financial interests exist.

\section{References}

Addison, W.D., Brumpton, G.R., Vallini, D.A., McNaughton, N.J., Davis, D.W., Kissin, S.A., Fralick, P.W., and Hammond, A.L. (2005) Discovery of distal ejecta from the $1850 \mathrm{Ma}$ Sudbury impact event. Geology 33:193-196.

Alleon, J., Bernard, S., Le Guillou, C., Marin-Carbonne, J., Pont, S., Beyssac, O., McKeegan, K.D., and Robert, F. (2016) Molecular preservation of $1.88 \mathrm{Ga}$ Gunflint organic microfossils as a function of temperature and mineralogy. Nat Commun 7, doi:10.1038/ncomms11977.

Alpern, B., Lemos de Sousa, M.J.L., Pinheiro, H.J., and Zhu, X. (1992) Optical Morphology of Hydrocarbons and Oil Progenitors in Sedimentary Rocks-Relations with Geochemical Parameters, Publicações do Museu e Laboratório Mineralógico e Geológico da Faculdade de Ciências do Porto, N. S., No. 3, Porto, Portugal.

Awramik, S.M., and Barghoorn, E.S. (1977) The Gunflint microbiota. Precambrian Res 5:121-142.

Barghoorn, E.S., and Tyler, S.A. (1965) Microorganisms from the Gunflint chert. Science 147:563-575.

Barghoorn, E.S., Knoll, A.H., Dembicki, H., Jr., and Meinschein, W.G. (1977) Variation in stable carbon isotopes in organic matter from the Gunflint Iron Formation. Geochim Cosmochim Acta 41:425-430.

Bengtson, S., Rasmussen, B., Ivarsson, M., Muhling, J.R., Broman, C., Marone, F., Stampanoni, M., and Bekker, A. (2017) Fungus-like mycelial fossils in 2.4 billion-year-old vesicular basalt. Nat Ecol Evol 1, doi:10.1038/s41559-0170141.

Bernard, S., and Horsfield, B. (2014) Thermal maturation of gas shale systems. Annu Rev Earth Planet Sci 42:635-651.

Bernard, S., Wirth, R., Schreiber, A., Schulz, H.-M., and Horsfield, B. (2012) Formation of nanoporous pyrobitumen residues during maturation of the Barnett Shale (Fort Worth Basin). Int J Coal Geol 103:3-11.

Brasier, M.D., Green, O.R., Jephcoat, A.P., Kleppe, A.K., Van Kranendonk, M.J., Lindsay, J.F., Steele, A., and Grassineau, N.V. (2002) Questioning the evidence for Earth's oldest fossils. Nature 416:76-81.

Brasier, M.D., Antcliffe, J., Saunders, M., and Wacey, D. (2015) Changing the picture of Earth's earliest fossils (3.5$1.9 \mathrm{Ga}$ ) with new approaches and new discoveries. Proc Natl Acad Sci USA 112:4859-4864.

Brocks, J.J. (2011) Millimeter-scale concentration gradients of hydrocarbons in Archean shales: live-oil escape or fingerprint of contamination? Geochim Cosmochim Acta 75: 3196-3213.

Buick, R. (1990) Microfossil recognition in Archaean rocks: an appraisal of spheroids and filaments from a $3500 \mathrm{M}$. Y. old chert barite unit at North Pole, Western Australia. Palaios 5: 441-459.

Buick, R., Rasmussen, B., and Krapez, B. (1998) Archean oil: evidence for extensive hydrocarbon generation and migration 2.5-3.5 Ga. Bull Am Assoc Petrol Geol 82:50-69.

Cady, S.L., and Farmer, J.D. (1996) Fossilization processes in siliceous thermal springs: trends in preservation along thermal gradients. In Evolution of Hydrothermal Ecosystems on Earth (and Mars?), edited by G.R. Bock and J.A. Goode, Ciba Foundation Symposium 202, John Wiley, Chichester, pp $150-173$.
Cady, S., Farmer, J.D., Grotzinger, J.P., Schopf, J.W., and Steele, A. (2003) Morphological biosignatures and the search for life on Mars. Astrobiology 3:351-368.

Camp, W.K. (2015) Diagenetic evolution of organic matter cements in unconventional shale reservoirs. American Association of Petroleum Geologists Search and Discovery Article No. 90216, American Association of Petroleum Geologists, Tulsa, OK, doi:10.1306/13672218M1211681.

Cloud, P. (1973) Paleoecological significance of banded ironformation. Econ Geol 68:1135-1143.

Cloud, P.E., Jr. (1965) Significance of the Gunflint (Precambrian) microflora. Science 148:27-35.

De Gregorio, B.T., Sharp, T.G., Flynn, G.J., Wirick, S., and Hervig, R.L. (2009) Biogenic origin for Earth's oldest putative microfossils. Geology 37:631-634.

Dodd, M.S., Papineau, D., Grenne, T., Slack, J.F., Rittner, M., Pirajno, F., O’Neil, J., and Little, C.T.S. (2017) Evidence for early life in Earth's oldest hydrothermal vent precipitates. Nature 543:60-64.

Edgerton, D. (1997) Reconstruction of the Red Dog Zn-Pb-Ba orebody, Alaska-implications for the vent environment during the mineralizing event. Can J Earth Sci 34:1581-1602.

Floran, R.J., and Papike, J.J. (1975) Petrology of the low-grade rocks of the Gunflint iron-formation, Ontario-Minnesota. Geol Soc Am Bull 86:1169-1190.

Fralick, P.W., Davis, D.W., and Kissin, S.A. (2002) The age of the Gunflint Formation, Ontario, Canada: single zircon U-Pb age determinations from reworked volcanic ash. Can J Earth Sci 39:1085-1091.

French, K.L., Hallmann, C., Hope, J.M., Buick, R., Brocks, J.J., and Summons, R.E. (2013) Archean hydrocarbon biomarkers: Archean or not? In Proceedings of Goldschmidt Conference, Florence, Italy, 25-30 August 2013, p 1110.

French, K.L., Hallmann, C., Hope, J.M., Schoon, P.L., Zumberge, J.A., Hoshino, Y., Peters, C.A., George, S.C., Love, G.D., Brocks, J.J., Buick, R., and Summons, R.E. (2015) Reappraisal of hydrocarbon biomarkers in Archean rocks. Proc Natl Acad Sci USA 112:5915-5920.

Furnes, H., Banerjee, N.R., Muehlenbachs, K., Staudigel, H., and de Wit, M. (2004) Early life recorded in Archean pillow lavas. Science 304:578-581.

García-Ruiz, J.M., Hyde, S.T., Carnerup, A.M., Christy, A.G., Van Kranendonk, M.J., and Welham, N.J. (2003) Selfassembled silica-carbonate structures and detection of ancient microfossils. Science 302:1194-1197.

Gong, J., Myers, K.D., Munoz-Saez, C., Homann, M., Rouillard, J., Wirth, R., Schreiber, A., and van Zuilen, M.A. (2020) Formation and preservation of microbial palisade fabric in silica deposits from El Tatio, Chile. Astrobiology 20: 500-524.

Goodwin, A.M. (1956) Facies relations in the Gunflint Iron Formation. Econ Geol 51:565-595.

Grosch, E.G., and McLoughlin, N. (2014) Reassessing the biogenicity of Earth's oldest trace fossil with implications for biosignatures in the search for early life. Proc Natl Acad Sci USA 111:8380-8385.

Hackley, P.C., and Cardott, B.J. (2016) Application of organic petrography in North American shale petroleum systems: a review. Int J Coal Geol 163:8-51.

Head, I.M., Jones, D.M., and Larter, S.R. (2003) Biological activity in the deep subsurface and the origin of heavy oil. Nature 426:344-352.

Hemming, S.R., McLennan, S.M., and Hanson, G.N. (1995) Geochemical and $\mathrm{Nd} / \mathrm{Pb}$ isotopic evidence for the provenance 
of the early Proterozoic Virginia Formation, Minnesota: implications for tectonic setting of the Animikie Basin. J Geol 103:147-168.

House, C.H., Schopf, J.W., McKeegan, K.D., Coath, C.D., Harrison, T.M., and Stetter K.O. (2000) Carbon isotopic composition of individual Precambrian microfossils. Geology 28:707-710.

Igisu, M., Ueno, Y., Shimojima, M., Nakashima, S., Awramik, S.M., Ohta, H., and Maruyama, S. (2009) Micro-FTIR signature of bacterial lipids in Proterozoic microfossils. Precambrian Res 173:19-26.

Jacob, H. (1989) Classification, structure, genesis and practical importance of natural solid oil bitumen ("migrabitumen"). Int J Coal Geol 11:65-79.

Jones, B., Renaut, R.W., and Rosen, M.R. (2001) Taphonomy of silicified filamentous microbes in modern geothermal sinters-implications for identification. Palaios 16:580-592.

Jørgensen, B.B., and Boetius, A. (2007) Feast and famine-microbial life in the deep-sea bed. Nat Rev Microbiol 5:770-781.

Knoll, A.H. (2012) The fossil record of microbial life. In Fundamentals of Geobiology, edited by A.H. Knoll, D.E. Canfield, and K. Konhauser, Wiley-Blackwell, Chichester, UK, pp 297-314.

Knoll, A.H., Barghoorn, E.S., and Awramik, S.M. (1978) New microorganisms from the Aphebian Gunflint Iron Formation, Ontario. J Paleontol 52:976-992.

Köhler, I., Konhauser, K.O., Papineau, D., Bekker, A., and Kappler, A. (2013) Biological carbon precursor to diagenetic siderite with spherical structures in iron formations. Nat Commun 4:1741.

Konhauser, K.O., Phoenix, V.R., Bottrell, S.H., Adams, D.G., and Head, I.M. (2001) Microbial-silica interactions in Icelandic hot spring sinter: possible analogues for some Precambrian siliceous stromatolites. Sedimentology 48:415-433.

Lanier, W.P. (1989) Interstitial and peloid microfossils from the $2.0 \mathrm{Ga}$ Gunflint Formation: implications for the paleoecology of the Gunflint stromatolites. Precambrian Res 45:291-318.

Leach, D.L., Marsh, E., Emsbo, P., Bombach, C.S., Kelley, K.D., and Anthony, M. (2004) Nature of hydrothermal fluids at the shale-hosted Red Dog Zn-Pb-Ag deposits, Brooks Range, Alaska. Econ Geol 99:1449-1480.

Lepot, K., Philippot, P., Benzerara, K., and Wang, G-Y. (2009) Garnet-filled trails associated with carbonaceous matter mimicking microbial filaments in Archean Basalt. Geobiology 7:393-402.

Lepot, K., Addad, A., Knoll, A.H., Wang, J., Troadec, D., Béché, A., and Javaux, E.J. (2017) Iron minerals within specific microfossil morphospecies of the $1.88 \mathrm{Ga}$ Gunflint Formation. Nat Commun 8, doi:10.1038/ncomms14890.

Lindsay, J.F., Brasier, M.D., McLoughlin, N., Green, O.R., Fogel, M., Steele, A., and Mertzman, S.A. (2005) The problem of deep carbon-an Archaean Paradox. Precambrian Res 143:1-22.

Lynne, B.Y., and Campbell, K.A. (2003) Diagenetic transformations (opal-A to quartz) of low- and mid-temperature microbial textures in siliceous hot-spring deposits, Taupo Volcanic Zone, New Zealand. Can J Earth Sci 40:1679_ 1696.

Mancuso, J.J., Kneller, W.A., and Quick, J.C. (1989) Precambrian vein pyrobitumen: evidence for petroleum generation and migration $2 \mathrm{Ga}$ ago. Precambrian Res 44:137-146.

Marshall, C.P., Emry, J.R., and Marshall, A.O. (2011) Haematite pseudomicrofossils present in the 3.5-billion-yearold Apex chert. Nat Geosci 4:240-243.
Marshall, A.O., Emry, J.R., and Marshall, C.P. (2012) Multiple generations of carbon in the Apex chert and implications for preservation of microfossils. Astrobiology 12:160-166.

McLoughlin, N., and Grosch, E.G. (2015) A hierarchial system for evaluating the biogenicity of metavolcanic- and ultramafic-hosted microalteration textures in the search for extraterrestrial life. Astrobiology 15:901-921.

Melezhik, V.A., Fallick, A.E., Filippov, M.M., Lepland, A., Rychanchik, D.V., Deines, Y.E., Medvedev, P.V., Romashkin, A.E., and Strauss, H. (2009) Petroleum surface oil seeps from a Palaeoproterozoic petrified giant oilfield. Terra Nova 21:119-126.

Misch, D., Gross, D., Hawranek, G., Horsfield, B., Klaver, J., Mendez-Martin, F., Urai, J.L., Vranjes-Wessely, S., Sachsenhofer, R.F., Schmatz, J., Li, J., and Zou, C. (2019) Solid bitumen in shales: petrographic characteristics and implications for reservoir characterization. Int J Coal Geol 205:14-31.

Moreau, J.W., and Sharp, T.G. (2004) A transmission electron microscopy study of silica and kerogen biosignatures in $\sim 1.9$ Ga Gunflint microfossils. Astrobiology 4:196-210.

Oehler, D.Z., and Cady, S.L. (2014) Biogenicity and syngeneity of organic matter in ancient sedimentary rocks: recent advances in the search for evidence of past life. Challenges 5: 260-283.

Oehler, D.Z., Robert, F., Walter, M.R., Sugitani, K., Allwood, A., Meibom, A., Mostefaoui, S., Selo, M., Thomen, A., and Gibson, E.K. (2009) NanoSIMS: Insights to biogenicity and syngeneity of Archaean carbonaceous structures. Precambrian Res 173:70-78.

Orange, F., Westall, F., Disnar, J.-R., Prieur, D., Bienvenu, N., Le Romancer, M., and Défarge, C. (2009) Experimental silicification of the extremophilic archaea Pyroccus abyssi and Methanocaldococcus jannaschii. Applications in the search for evidence of life in early Earth and extraterrestrial rocks. Geobiology 7:403-418.

Orange, F., Disnar, J.-R., Gautret, P., Westall, F., Bienvenu, N., Lottier, N., and Prieur, D. (2012) Preservation and evolution of organic matter during experimental fossilisation of the hyperthermophilic archaea Methanocaldococcus jannaschii. Orig Life Evol Biosph 42:587-609.

Papineau, D., She, Z., and Dodd, M.S. (2017) Chemically oscillating reactions during the diagenetic oxidation of organic matter and in the formation of granules in late Palaeoproterozoic chert from Lake Superior. Chem Geol 470:33-54.

Planavsky, N., Rouxel, O., Bekker, A., Shapiro, R., Fralick, P., and Knudsen, A. (2009) Iron-oxidizing microbial ecosystems thrived in late Paleoproterozoic redox-stratified oceans. Earth Planet Sci Lett 286:230-242.

Poulton, S.W., Fralick, P.W., and Canfield, D.E. (2004) The transition to a sulphidic ocean $\sim 1.84$ billion years ago. Nature 431:173-177.

Rasmussen, B. (2000) Filamentous microfossils in a 3,235million-year-old volcanogenic massive sulphide deposit. Nature 405:676-679.

Rasmussen, B. (2005) Evidence for pervasive petroleum generation and migration in 3.2 and 2.63 billion-year old shales. Geology 33:497-500.

Rasmussen, B., and Buick, R. (2000) Oily old ores: evidence for hydrothermal petroleum generation in an Archean volcanogenic massive sulfide deposit. Geology 28:731-734.

Rasmussen, B., and Glover, J.E. (1996) Fluid evolution interpreted from diagenetic assemblages and salinity data in Permo-Triassic sandstone, northern Perth Basin, Western Australia. J Sed Res 66:492-500. 
Rasmussen, B., and Muhling, J.R. (2019a) Evidence for widespread oil migration in $1.88 \mathrm{Ga}$ Gunflint Formation. Geology 47:899-903.

Rasmussen, B., and Muhling, J.R. (2019b) Organic-rich microfossils produced by oil infiltration of hollow silicified bacteria: evidence from the ca. 340 Ma Red Dog $\mathrm{Zn}-\mathrm{Pb}$ deposit, Alaska. Geology 47:1107-1111.

Rasmussen, B., Fletcher, I.R., Brocks, J.J., and Kilburn, M.R. (2008) Reassessing the first appearance of eukaryotes and cyanobacteria. Nature 455:1101-1104.

Rasmussen, B., Fletcher, I.R., Bekker, A., Muhling, J.R., Gregory, C.J., and Thorne, A. (2012) Deposition of 1.88 billion-year-old iron formations as a consequence of rapid crustal growth. Nature 484:498-501.

Schopf, J.W., and Packer, B.M. (1987) Early Archean (3.3billion to 3.5-billion-year-old) microfossils from Warrawoona Group, Australia. Science 237:70-73.

Schopf, J.W., Kudryavtsev, A.B., Agresti, D.G., Wdowiak, T.J., and Czaja, A.D. (2002) Laser-Raman imagery of Earth's earliest fossils. Nature 416:73-76.

Schopf, J.W., Kudryavtsev, A.B., Agresti, D.B., Czaja, A.D., and Wdowiak, T.J. (2005) Raman imagery: a new approach to assess the geochemical maturity and biogenicity of permineralized Precambrian fossils. Astrobiology 5:333-371.

Schultze-Lam, S., Ferris, F.G., Konhauser, K.O., and Wiese, R.G. (1995) In situ silicification of an Icelandic hot spring microbial mat: implications for microfossil formation. Can J Earth Sci 32:2021-2026.

Sforna, M.C., van Zuilen, M.A., and Philippot, P. (2014) Structural characterization by Raman hyperspectral mapping of organic carbon in the 3.46 billion-year-old Apex chert, Western Australia. Geochim Cosmochim Acta 124:18-33.

Shapiro, R.S., and Konhauser, K.O. (2015) Hematite-coated microfossils: primary ecological fingerprint or taphonomic oddity of the Paleoproterozoic? Geobiology 13:209-224.

Slack, J.F., Selby, D., and Dumoulin, J.A. (2015) Hydrothermal, biogenic, and seawater components in metalliferous black shales of the Brooks Range, Alaska: synsedimentary metal enrichment in a carbonate ramp setting. Econ Geol 110:653675.

Strother, P.K., and Tobin, K. (1987) Observations on the genus Huroniospora Barghoorn: implications for paleoecology of the Gunflint microbiota. Precambrian Res 36:323-333.

Tyler, S.A., and Barghoorn, E.S. (1954) Occurrence of structurally preserved plants in Pre-Cambrian rocks of the Canadian Shield. Science 119:606-608.

van Zuilen, M.A., Chaussidon, M., Rollion-Bard, C., and Marty, B. (2007) Carbonaceous cherts of the Barberton Greenstone Belt, South Africa: isotopic, chemical and structural characteristics of individual microstructures. Geochim Cosmochim Acta 71:655-669.

Wacey, D. (2009) Early Life on Earth: A Practical Guide, Springer Science \& Business Media, New York.

Wacey, D., Menon, S., Green, L., Gerstmann, D., Kong, C., Mcloughlin, N., Saunders, M., and Brasier, M. (2012) Taphonomy of very ancient microfossils from the $3400 \mathrm{Ma}$
Strelley Pool Formation and 1900 Ma Gunflint Formation: new insights using a focused ion beam. Precambrian Res 220:234-250.

Wacey, D., McLoughlin, N., Kilburn, M.R., Saunders, M., Cliff, J.B., Kong, C., Barley, M.E., and Brasier, M.D. (2013) Nanoscale analysis of pyritized microfossils reveals differential heterotrophic consumption in the $\sim 1$.9-Ga Gunflint chert. Proc Natl Acad Sci USA 110:8020-8024.

Wacey, D., Saunders, M., Kong, C., Brasier, A., and Brasier, M. (2016) $3.46 \mathrm{Ga}$ Apex chert 'microfossils' reinterpreted as mineral artefacts produced during phyllosilicate exfoliation. Gondwana Res 36:296-313.

Walsh, M.M. (1992) Microfossils and possible microfossils from the Early Archean Onverwacht Group, Barberton Mountain Land, South Africa. Precambrian Res 54:271-293.

Westall, F. (1999) The nature of fossil bacteria: a guide to the search for extraterrestrial life. J Geophys Res 104:1643716451.

Westall, F., Boni, L., and Guerzoni, M.E. (1995) The experimental silicification of microorganisms: Palaeontology 3: 495-528.

Williford, K.H., Ushikubo, T., Schopf, J.W., Lepot, K., Kitajima, K., and Valley, J.W. (2013) Preservation and detection of microstructural and taxonomic correlations in the carbon isotopic compositions of individual Precambrian microfossils. Geochim Cosmochim Acta 104:165-182.

Address correspondence to:

B. Rasmussen

School of Earth Sciences

The University of Western Australia

Perth, WA 6009

Australia

E-mail: Birger.Rasmussen@uwa.edu.au

Submitted 16 September 2020

Accepted 17 December 2020

Associate Editor: Russell Shapiro

Abbreviations Used
CMCA $=$ Centre for Microscopy, Characterisation
$\quad$ and Analysis
EDS $=$ energy dispersive X-ray spectrometry
$\mathrm{FIB}=$ focused ion beam
$\mathrm{HAAF}=$ high-angle annular dark-field
$\mathrm{OWC}=$ oil-water contact
$\mathrm{SEM}=$ scanning electron microscopy
$\mathrm{STEM}=$ scanning transmission electron microscope
$\mathrm{TEM}=$ transmission electron microscopy
transmission electron microscope
$\mathrm{UWA}=$ University of Western Australia

